\title{
NONLINEAR STATIC VS. INCREMENTAL DYNAMIC ANALYSIS OF INFILLED FRAMES WITH OPEN FIRST FLOOR
}

\author{
NELINEARNA STATIČKA NASUPROT INKREMENTALNE DINAMIČKE ANALIZE \\ OKVIRA SA ISPUNOM SA OTVORENOM PRVOM ETAŽOM
}

\author{
Koce TODOROV \\ Ljupco LAZAROV
}

ORIGINALNI NAUČNI RAD

ORIGINAL SCIENTIFIC PAPER

UDK:624.072.33:692.2

doi:10.5937/GRMK1804003T

\section{INTRODUCTION}

The evaluation of the seismic performance of existing and newly designed structures is a relatively complex and multidisciplinary process. It includes elements of engineering seismology and soil dynamics, necessary to define the level of seismic hazard and the expected characteristics of input ground motion, elements of the dynamics of structures, for determination of the structural response, as well as elements of the structural mechanics, necessary for the accurately inclusion of the effects of material nonlinearity in the response of the systems under consideration, [2], [14], [22], [25].

Having in mind the expected structural behaviour to the permanent or seismic action, it would be logical to select appropriate analysis methods that can predict the structural behaviour with a high degree of confidentiality. If linear behaviour can be successfully predicted using linear methods for analysis, then it is expected that a nonlinear response should be determined with nonlinear analysis methods. Despite these expectations and considerable efforts for the conceptual transformation of earthquake engineering that have been made in the last twenty years, the generally accepted methods for seismic analysis are based on linear approximations. And these approximations are acceptable, if a certain number of effects are included in the process of analysis or design. Masonry infill, the influence of cracks in reinforced concrete elements, the contribution of effective slab width, soil - structure interaction, etc. are

Koce TODOROV, Assistant Professor, Ss. Cyril and Methodius University in Skopje, Faculty of Civil Engineering, Skopje, Republic of Macedonia, todorov@gf.ukim.edu.mk

Ljupco LAZAROV, Professor, Ss. Cyril and Methodius University in Skopje, Faculty of Civil Engineering, Skopje, Republic of Macedonia, lazarov@gf.ukim.edu.mk some of the parameters which can significantly change the desired seismic response of the analysed structures.

\section{ROLE OF MASONRY INFILL ON THE SEISMIC BEHAVIOUR OF STRUCTURES}

Reinforced concrete frames with masonry infill are often used structural systems in construction practice worldwide. In this type of structures, the external and internal walls made of different materials, usually of ceramic blocks and bricks, are built as infill panels between reinforced concrete structural elements. Masonry infill is characterized with significant strength and stiffness and it can greatly alter the response of structures exposed to dynamic loads. The infill panels increase the structural stiffness, strength and damping and act as a first line of defence in seismic activity, reducing the ductility demand and consequent damage of structural elements. However irregular distribution of infill in plane and along building height can lead to series of unfavourable effects (torsion effects, dangerous collapse mechanisms, soft or weak storey, variations in the vibration period, etc.). That is why different opinions about the influence of the infill on the seismic behaviour of the structures can be found in the scientific and expert community [10], [15], [21], [29].

The presence of infill significantly changes the mechanism for lateral load redistribution [24]. Thus, the predominant frame system, in which the elements are exposed to bending, is transformed into a predominant truss system whose elements are generally exposed to axial action, Fig. 1.

Although this is an undeniable fact, according to the usual design practice, the interaction between the infill and the frame structure is most often neglected. This can lead to significant errors in determining the stiffness, bearing capacity and ductility of the analysed structure, which can especially be emphasized in reinforced 
concrete frames with discontinuity in the distribution of the masonry infill to the height of the building. Such structures in the literature are known as building with a weak floor (the strength on the lower floor is less than the strength of the upper floors), or structures with flexible or soft floor (the horizontal stiffness on the considered floor is lower than the stiffness of the upper floors). Although from a structural point of view these systems are unfavourable, for architectural or commercial reasons, they are quite attractive and exploited, especially in the central city cores and in densely populated urban areas. The open free space of such facilities, which is usually located on the first floor, is used as a corridor or as a space for accommodation in parking lots, shops, administration, etc., Fig. 2.

The influence of the infill on the seismic performance of reinforced concrete structures designed according to different national regulations has been the subject of a significant number of researches available in the literature, [6], [7], [9], [13], [16], [17], [18], [19], [21], [27].

\section{DESCRIPTION OF ANALYSED STRUCTURES}

In order to analyse the influence of the masonry infill on the behaviour of reinforced concrete frames that have been designed without taking into account the influence of the infill, a series of nonlinear static and dynamic analyses was conducted in this research. All analysed frames have been designed without taking into account the influence of the infill. In the phase of nonlinear assessment, all frames were additionally upgraded with the presence of masonry infill. Nonlinear static analyses were performed for bare and infilled frames. Two different distributions of infill panels were analysed: fully infill frames (FI) and infilled frames with open first floor (OS). Nonlinear dynamic analyses were performed for bare and infilled 2D frames with an open floor exposed to earthquakes with different intensities and with different frequency content. All numerical analyses were performed by the computer program SeismoStruct v6.0 [26].

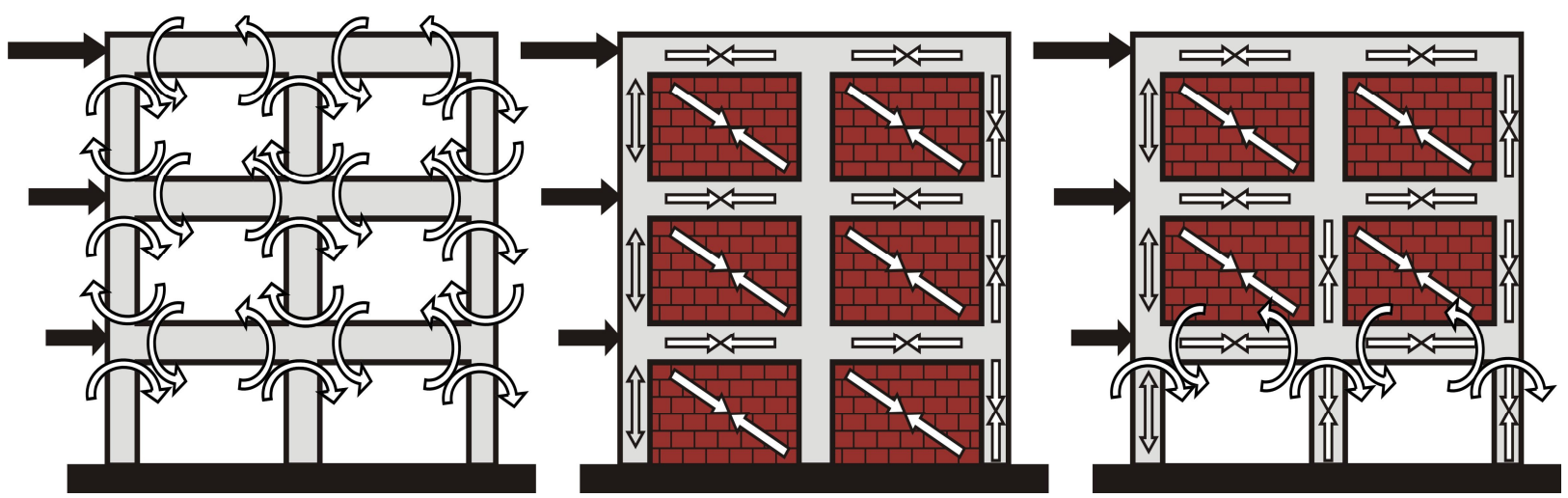

Fig. 1. Changes in the lateral load transfer mechanism owing to inclusion of masonry infill walls. (adopted from Murthy and Jain [24])
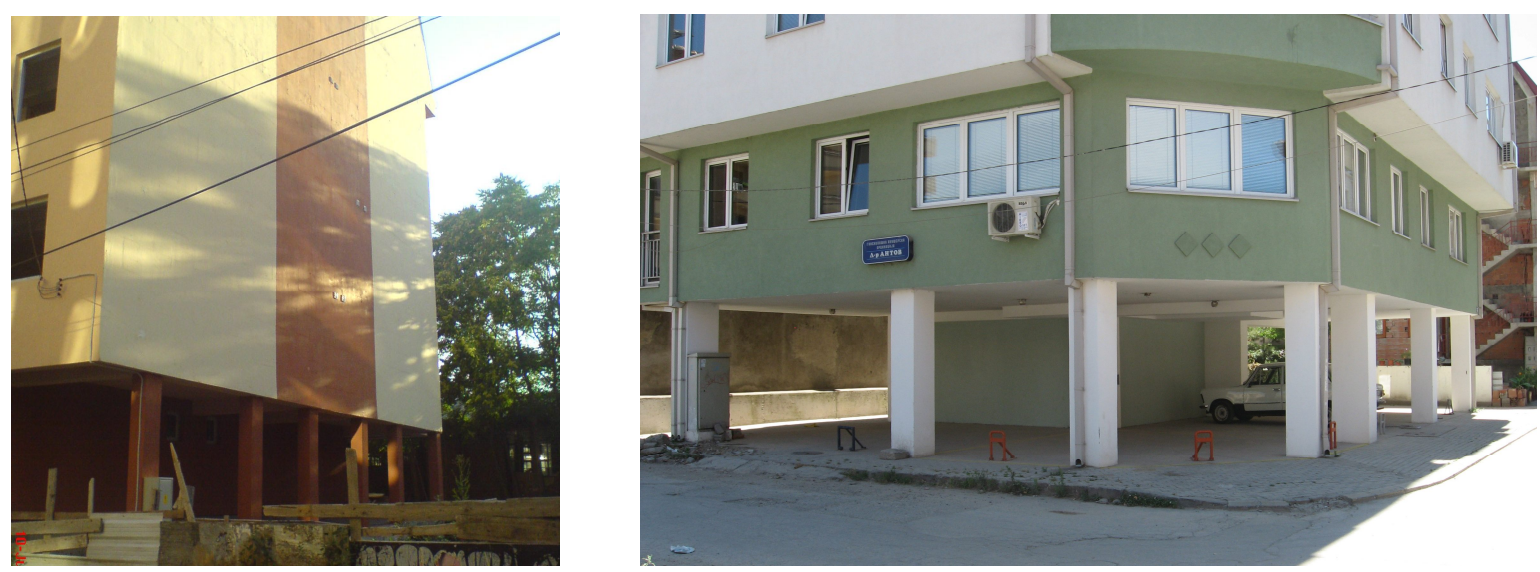

Fig. 2. Reinforced concrete buildings with open first floor 


\subsection{Design parameters}

In order to cover structures with different dynamic characteristics, six reinforced concrete plane frames with different number of storeys ( $n=2,3,5,7,10$ and 13), in the following text marked as frames R1, R2, R3, R4, R5 and $R 6$, are generated in this investigation. All analysed structures are designed as three bay plane frames with a span of $5 \mathrm{~m}$ and a constant storey height of $3 \mathrm{~m}$. The frames are designed to represent the exterior frame of a reinforced concrete spatial frame structure, Fig. 3. After the distribution of the surface load on the frames in both orthogonal directions, the beams of analysed frames were exposed to uniform load of $25 \mathrm{kN} / \mathrm{m}^{\prime}$ on the floors and $15 \mathrm{kN} / \mathrm{m}$ ' on the roof. At the beam - column joints additional concentrated forces, which represent the influence of the beams in the longitudinal direction, was applied. For the purpose of dynamic analysis and according to the defined loads, the distribution of the mass by floors, equal to $70.9 \mathrm{t}$ at each floor, and $38.2 \mathrm{t}$ at the level of the roof, was determined. A schematic representation of distribution of the gravity loads and the storey mass of the analysed frames is presented in Fig. 3 .

The design of frames is done according to the actual Code of technical regulations for the design and construction of buildings in seismic regions, 1981 [31]. The total mass of the analysed frames $\left(\mathrm{M}_{\mathrm{tot}}\right)$, the fundamental period of vibration $T_{1}$, the determined seismic design force (S), for the seismic intensity level IX (MCS), the ratio between the seismic design force and the weight of the frame $(S / G)$, the maximum top displacement obtained from the action of the seismic forces $\left(d_{\max }\right)$ and the maximum stresses in the columns obtained from the action of the gravity loads are presented in Table 1.

Concrete with compressive cube strength of $30 \mathrm{MPa}$ (MB30), and reinforcement with yield strength of $400 \mathrm{MPa}$ (RA400/500) were used for the design of structural elements. In the columns of all frames, a minimum reinforcement ratio of $1 \%$ has been adopted, although this requirement is not explicitly set out in the Code. In order to increase the ductility of the beams, in the sections above the supports where plastic hinges are expected, a compression zone reinforcement at least $50 \%$ of the area of the tensile reinforcement is placed. The adopted dimensions of the structural elements and the adopted reinforcement in cross sections for all generated frames are shown in Fig. 4.
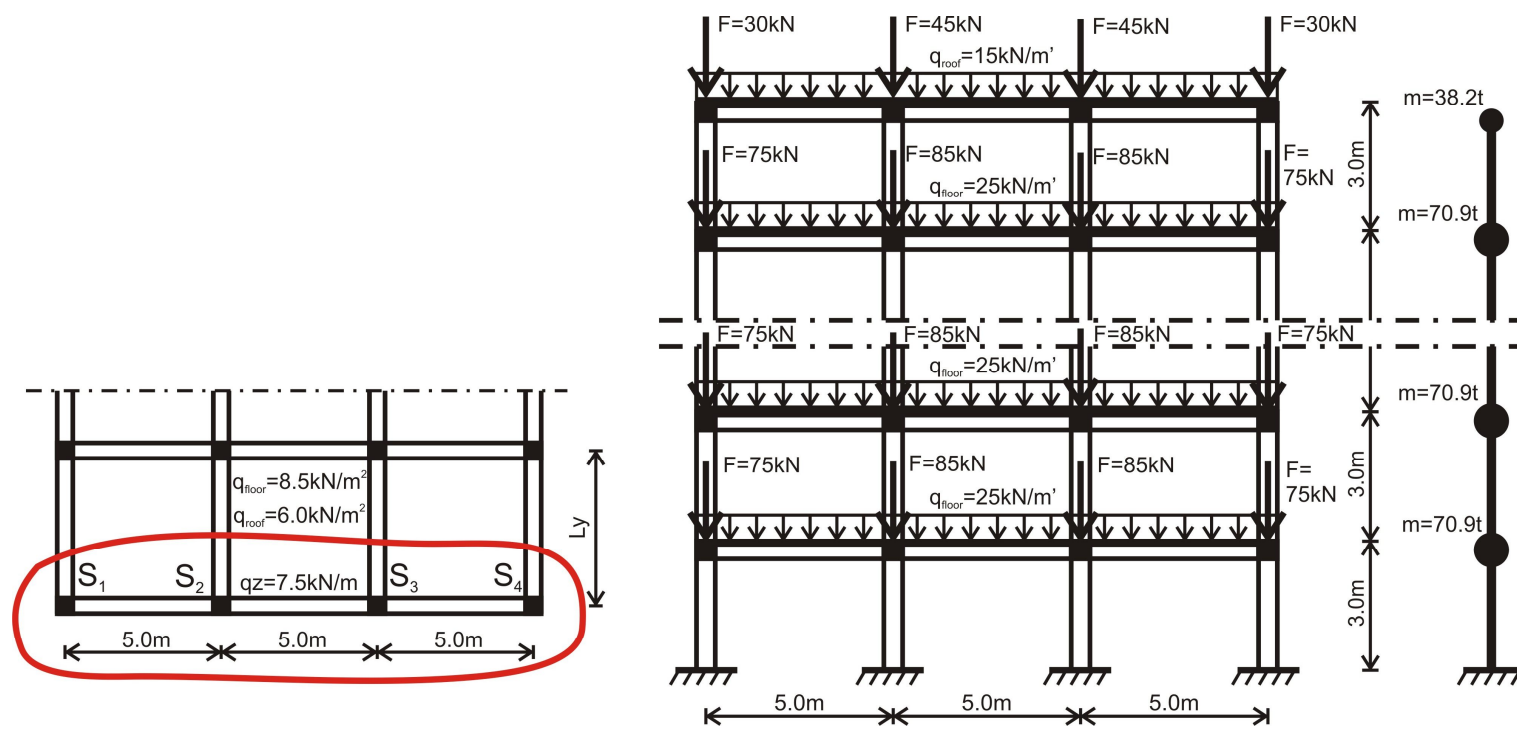

Fig. 3. Schematic representation of analysed frame structures

Table 1. Design characteristics of analysed frame

\begin{tabular}{ccccccccc}
\hline Frame & $\begin{array}{c}\text { Num. of } \\
\text { storeys }\end{array}$ & $\begin{array}{c}\mathrm{M}_{\text {tot }} \\
(\mathrm{t})\end{array}$ & $\mathrm{T}_{1}(\mathrm{sec})$ & $\begin{array}{c}\mathrm{S} \\
(\mathrm{kN})\end{array}$ & $\mathrm{S} / \mathrm{G}$ & $\delta_{\max }(\mathrm{cm})$ & $\begin{array}{c}\delta_{\max } / \\
(\mathrm{H} / 600)\end{array}$ & $\begin{array}{c}\sigma_{0}(\mathrm{~g}+\mathrm{p}) \\
(\mathrm{MPa})\end{array}$ \\
\hline $\mathrm{R} 1$ & 2 & 109.1 & 0.432 & 107.0 & 0.1 & 0.651 & 0.65 & 3.76 \\
$\mathrm{R} 2$ & 3 & 180.0 & 0.517 & 176.6 & 0.1 & 1.075 & 0.72 & 4.57 \\
$\mathrm{R} 3$ & 5 & 321.8 & 0.609 & 315.7 & 0.1 & 1.526 & 0.61 & 4.81 \\
R4 & 7 & 463.6 & 0.820 & 388.2 & 0.085 & 2.668 & 0.76 & 5.70 \\
R5 & 10 & 676.3 & 1.071 & 433.5 & 0.065 & 3.482 & 0.70 & 5.60 \\
R6 & 13 & 889.0 & 1.386 & 440.2 & 0.05 & 4.586 & 0.71 & 6.06 \\
\hline
\end{tabular}



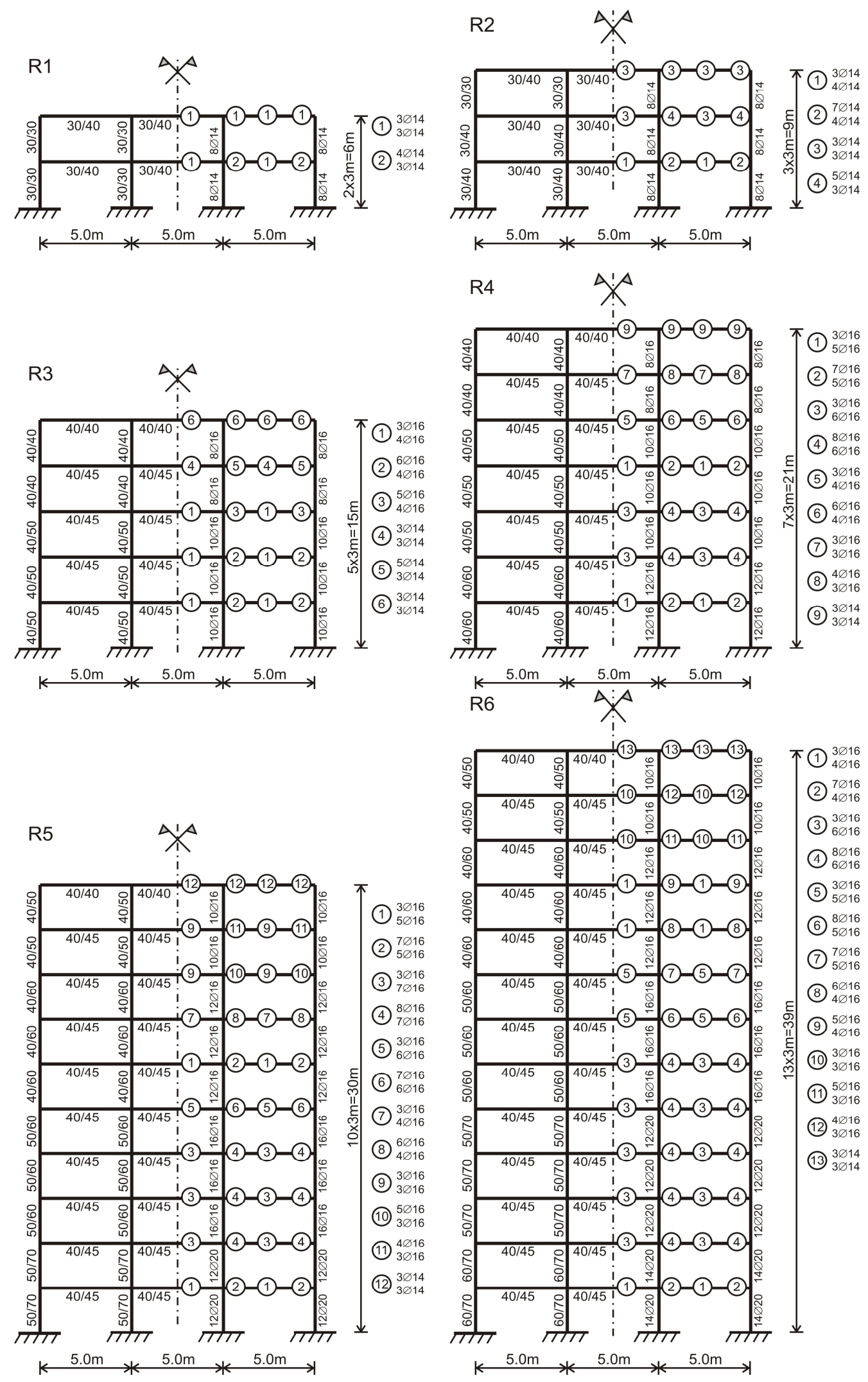

Fig. 4. Adopted dimensions and reinforcement in the cross sections of the analysed frames 


\subsection{Modelling assumptions}

For the modelling of reinforced concrete elements, the model of distributed plasticity with the displacement based formulation of finite elements is used. Each structural element is divided into four subsections with different lengths. For the purpose of numerical integration, the cross sections in Gauss integration points are discretised with a triangular mesh of elements - fibres, with an optimal mesh density of about 100 fibres per cross-section. During the analysis, each fibre of cross-section is exposed to a uniaxial state of stress. Internal forces are obtained by numerical integration of stresses in the individual fibres. Mander's RC model [20] for confined and unconfined concrete and Menegoto Pinto steel model with the Monti - Nuti buckling rules [23] for the longitudinal reinforcement was used to describe the stress - strain relationship in individual fibres. The nonlinear behaviour of masonry infill was modelled with the equivalent diagonal strut, using the model developed by Crisafulli [5], [28].

\subsection{Adapted features of masonry infill}

Masonry infill was defined with two different strength and stiffness characteristics, namely weak infill (WI) and strong infill (SI). The weak infill is characterized by the compression strength in the diagonal direction $\mathrm{f}_{\mathrm{m}}=0.8 \mathrm{MPa}$ and a thickness of $15 \mathrm{~cm}$., while the strong infill has a compression strength of $1.2 \mathrm{MPa}$ and a thickness of $25 \mathrm{~cm}$. An initial modulus of elasticity equal to $1500 f_{m}$ was adopted for both types of infill. The compression strength is reached at strains of 0.002 , while complete degradation of the strength and stiffness of the infill occurs at ultimate dilatation of $1 \%$. The secant modulus of elasticity, at the point of achievement of compression strength is equal to one third of the initial modulus of elasticity, $E_{s e c}=500 f_{m}$. For defining the characteristics of the shear spring in the used material model, the initial shear bond strength of the infill $\tau_{0}=0.3 \mathrm{MPa}$ and coefficient of friction $\mu=0.5$ were adopted. The maximum shear strength $\tau_{\max }$ was limited to $0.6 \mathrm{MPa}$.

According to the adopted concept of modelling masonry infill, a compression strut is characterised with variable area which reduction is a function of the reached axial strains. The initial area of compression strut is a product of the thickness of the infill and the width of the equivalent diagonal, for which a value of $20 \%$ of the length of the diagonal is adopted. When strains in infill reach the value $\varepsilon_{1}=0.0005$, the area of the diagonal begins to decrease linearly. At strain equal to 0.0063 , its area is $50 \%$ of the initial. Schematic diagrams of stress - strain relationship for masonry infill, reduction of strut area and defined diagram lateral force - interstorey drift for masonry infill panel are presented in Fig. 5.

The limit values of the adopted strains correspond to a certain level of damage in masonry infill and according to the (Eq.1), can be directly connected with the achieved inter-storey drifts.

$$
\varepsilon=\frac{\delta}{2} \sin 2 \theta
$$

Strains at the beginning of the strut area reduction correspond to the state of cracks in the infill, which occur at inter-storey drift in range from $0.05 \%$ to $0.15 \%$. These range of inter-storey drifts correspond to the operational seismic performance level.

Strain at maximum strength in the infill correspond to inter-storey drift from $0.4 \%$ to $0.5 \%$ and according to the performance level represent the end of the immediate occupancy state. The strains at the end of the diagonal area reduction correspond to inter-storey drift of $1 \%$ to $2 \%$ and are the limit values of the life safety performance level. The ultimate strain in the infill which corresponds to inter-storey drift in the range from 2-3\% according to the level of seismic performance represents the collapse prevention limit state. The boundary ranges and the adopted values of strains for this research and corresponding inter-storey drifts for different performance levels are given in Table 2.

\section{NONLINEAR STATIC ANALYSIS}

Nonlinear static analysis is performed for the action of constant gravity load, which represents the initial state of stress and deformation in the structural elements and for the action of a monotonically increasing lateral load, which represents the inertial seismic forces initiated by the action of the seismic impact. It is well known that results of the nonlinear static analysis are strongly dependent on the pattern of distribution of the lateral force. Taking into account that in the frames with an open first floor, the effective modal mass in the first mode shape is over $80 \%$ of the total mass for all frames, i.e. over $90 \%$ for frames R1 to R4 with a strong infill and for frames R1 to R3 with a weak infill, in the further analyses assumed distribution of the lateral load according to the first mode shape was used. This assumption is

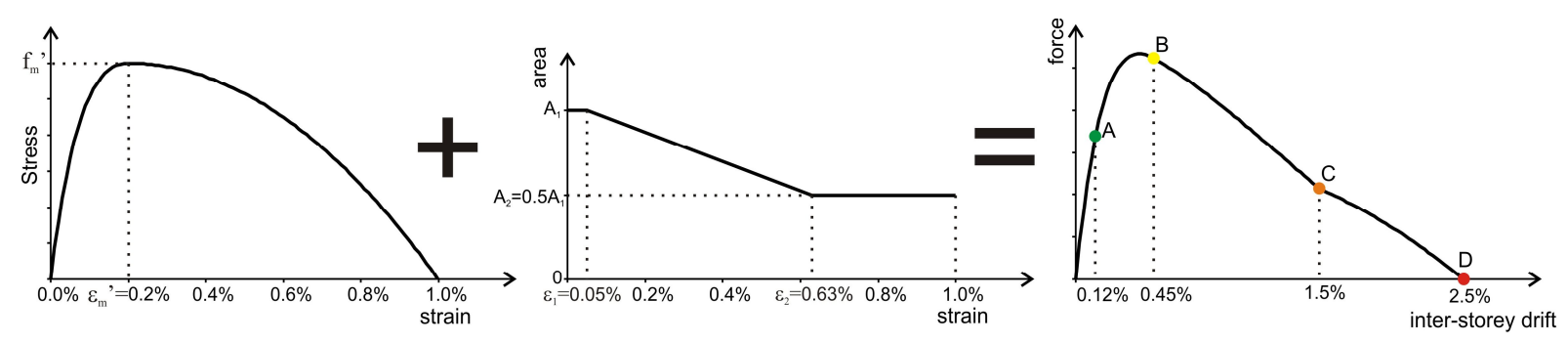

Fig. 5. Stress - strain relationship for masonry infill, reduction of strut area and defined diagram lateral force - interstorey drift for masonry infill panel 
Table 2. Performance level and corresponding boundary values of inter-storey drifts and strain in masonry infill

\begin{tabular}{|c|c|c|c|c|c|}
\hline Performance level & Range & $\begin{array}{c}\text { Boundary } \\
\text { values of } \\
\text { strain } \\
\end{array}$ & $\begin{array}{l}\text { Adopted } \\
\text { strain limit }\end{array}$ & $\begin{array}{c}\text { Boundary values } \\
\text { of inter-storey } \\
\text { drifts }\end{array}$ & $\begin{array}{l}\text { Adopted values of } \\
\text { inter-storey drifts }\end{array}$ \\
\hline Operational & $0-A$ & $\begin{array}{c}\varepsilon_{\mathrm{A}} \\
0.02-0.07 \%\end{array}$ & $0.05 \%$ & $\begin{array}{c}\delta_{\mathrm{A}} \\
0.05-0.15 \%\end{array}$ & $0.12 \%$ \\
\hline Immediate occupancy & $A-B$ & $\begin{array}{c}\varepsilon_{\mathrm{B}} \\
0.1-0.3 \%\end{array}$ & $0.2 \%$ & $\begin{array}{c}\delta_{\mathrm{B}} \\
0.25-0.7 \%\end{array}$ & $0.45 \%$ \\
\hline Life safety & $B-C$ & $\begin{array}{c}\varepsilon_{C} \\
0.4-0.85 \%\end{array}$ & $0.63 \%$ & $\begin{array}{c}\delta_{\mathrm{C}} \\
1-2 \%\end{array}$ & $1.5 \%$ \\
\hline Collapse prevention & C-D & $\begin{array}{c}\varepsilon_{C} \\
0.75-1.25 \%\end{array}$ & $1 \%$ & $\begin{array}{c}\delta_{D} \\
2-3 \%\end{array}$ & $2.5 \%$ \\
\hline
\end{tabular}

based on the fact that with the development of nonlinearities in the structural elements the participation of the effective modal mass of the dominant mode shape is usually increased. It should be noted that the distribution according to the first mode shape, determined for an undamaged structure, assumes the invariance of the mode shapes in function of the damage, which is usually false. However, changes in mode shapes, due to the influence of material nonlinearity, are usually small and do not have a major impact on the results of nonlinear static analysis, although the changes in vibration periods due to a reduction in the horizontal stiffness can be significant.

\subsection{Capacity curves}

The capacity curves for the analysed frames without and with masonry infill, determined for the distribution of the lateral load according to the first mode shape, are presented in Fig. 6.

On the vertical axis, the total base shear, expressed as a percentage of the total weight of the frame is displayed, while the horizontal axis shows the top displacements as a percentage of the total height of the frame (top drift). The curves are also marked by the points of appearance of the first plastic hinge in the structure, the points of formation of the mechanism, as well as the level of the design seismic force increased by $30 \%$. The appearance of the first plastic hinge is defined by determination of the step in the analysis when the strain of the longitudinal reinforcement in any section of the frame elements reaches yield strains, which is $0.2 \%$. The state of plastic mechanism formation is reached in the moment when plastic hinges occurs in at least two cross sections of all four columns of the considered frame.
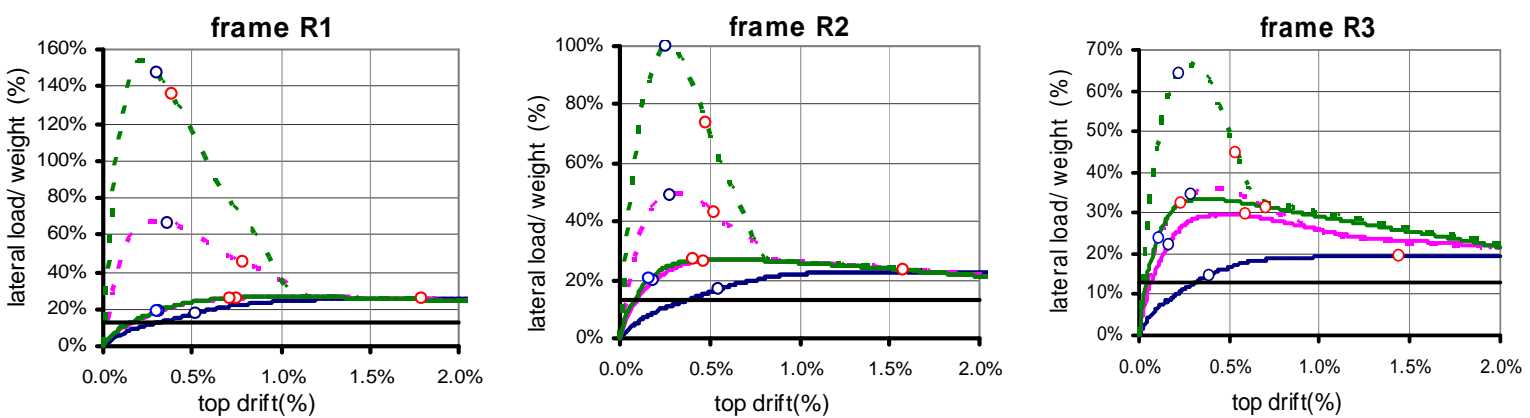

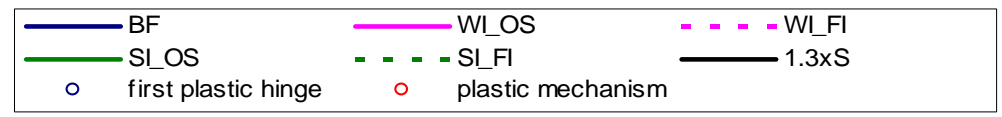
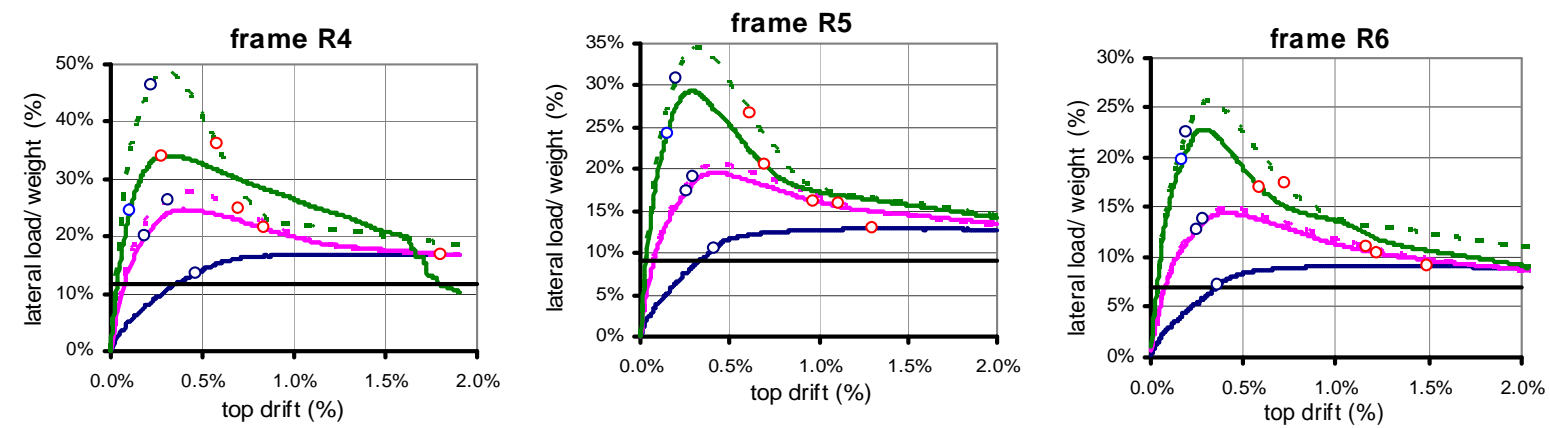

Fig. 6. Capacity curves of analysed frames 

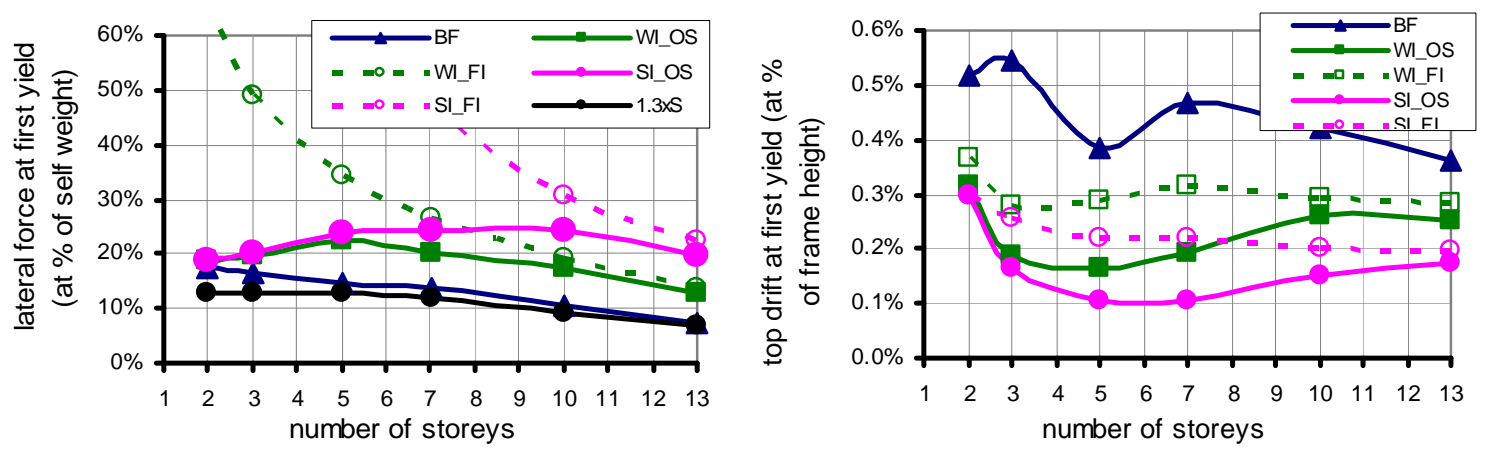

Fig. 7. Lateral force and top drift at occurrence of first plastic hinge for infilled and bare frames

From the diagrams presented in Fig. 6, it can be noticed that the masonry infill has favourable effects on the bearing capacity of the analysed frames, by increasing the level of the lateral force that causes the appearance of the first plastic hinge, as well as, by increasing the maximum capacity of the frames. The level of lateral force, as well as, the top drift at moment of first plastic hinge appearance for the infilled and bare frames is presented in Fig. 7.

Increasing the level of the lateral load at first plastic hinge in the infilled frames, compared to the bare frames, is a result of the redistribution of the internal forces due to the influence of the infill. Unlike the bare frames, where the first plastic hinge occurs in the beam elements of the lower storeys, in the frames with an open first floor, the first plastic hinge usually occurs in the support of one of the columns, Fig. 9.

The ratio between the lateral load at appearance of the first plastic hinge in the frame with the open floor and the bare frame, rises while increasing the number of storeys. This ratio is greater in the high rise frames with strong infill compared to the infilled frames with weak infill. Unlike open storey frames, in frames with a continuous infill, the ratio between the yield force for the infilled and bare frames decreases with increasing a number of storeys. At the highest frame the lateral load at the first plastic hinge formation for frames with open ground floor and frames with continuous infill is almost the same, indicating that the impact of the infill absence in the first floor is reduced by increasing the number of storeys, making the frames with the open floor to behave approximately in the same way as the frames with a continuous infill. Unlike the level of lateral load, the top drift at yield decreases due to the presence of the infill. The infilled frames reach the yield strength at smaller top

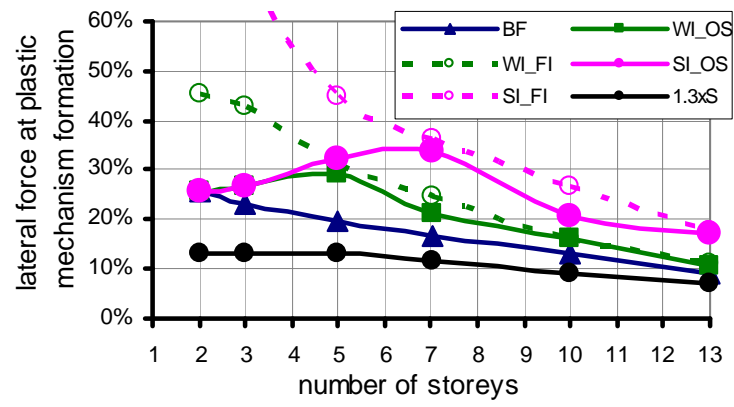

displacement compared to the bare frames, Fig.6. The yield displacements in frames with weak infill are greater than the displacements in the appropriate frames with strong infill. This ratio is quite small in the frames $R 1$ and $\mathrm{R} 2$, and rises with increasing a number of storeys. Top drift and the level of the lateral force, expressed as a weight ratio, obtained at the moment of plastic mechanism formation for the analysed frames are presented in Fig. 8.

The lateral force at the moment of plastic mechanism formation in low rise open storey frames is approximately the same as the lateral force in the respective bare frames, and is significantly less than the lateral force in the frames with continuous infill. With increasing a number of storeys, the differences between open storey frames and frames with continuous infill are reduced, while the differences between bare frames and open storey frames increases. In all frames with continuous infill, and in the frames R5 and R6 with open ground floor, the level of lateral force at mechanism formation is less than the level of force at the beginning of the yield. At the bare frames, the top drift at the moment of plastic mechanism formation ranges from $1.45 \%$ to $1.8 \%$, while at the infilled frames these displacements are 2 to 6 times smaller. On the bare frames the plastic mechanism is manifested through the formation of plastic hinges at the ends of the beams almost along the entire height of the frames, while in the infilled frames a plastic mechanism is expressed through a soft story mechanism formed by the appearance of plastic hinges at both ends of the columns on the ground floor, or through a combination of the formation of plastic hinges at the ends of the beams and columns on the lower storeys, Fig. 9.

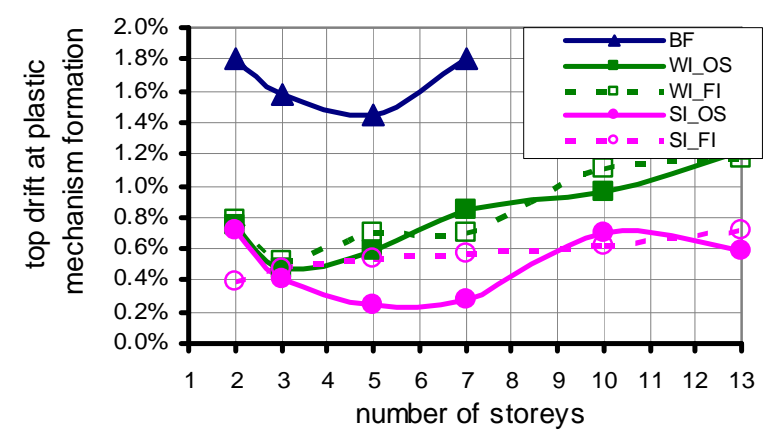

Fig. 8. Lateral force and top drift at the moment of plastic mechanism formation 


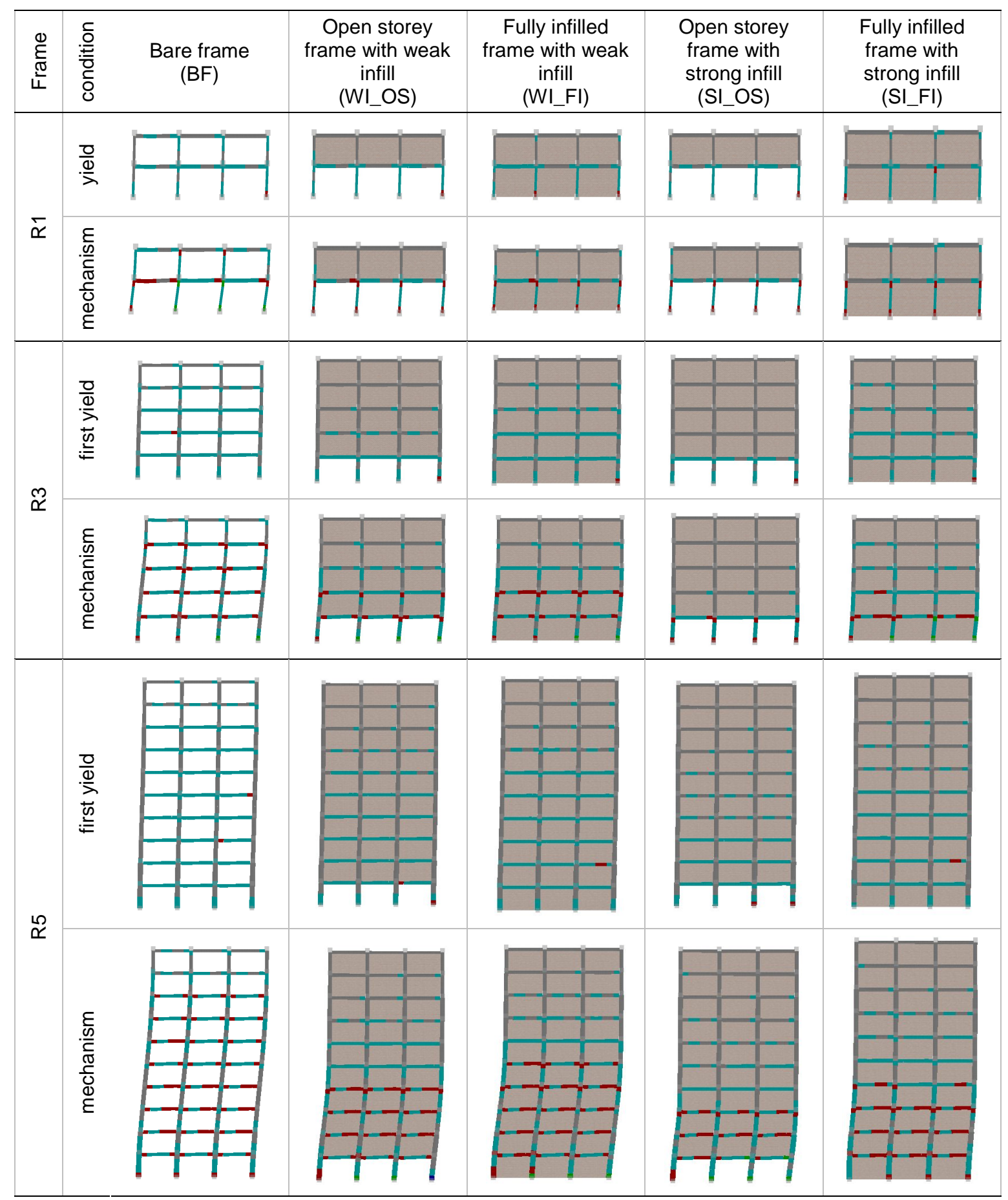

Fig. 9. Occurrence of the first plastic hinge and plastic mechanism formation for analysed frames

The state of occurrence of the first plastic hinge and the state of mechanism formation for the analysed frames is shown in Fig. 9. The blue colour indicates an element in which the condition of the appearance of first crack is reached; red colour represents the sections in which the yield strain in tensile reinforcement are reached; green colour marks a cross section at which the ultimate strain in the concrete cover is achieved, while the dark blue colour marks sections in which strains reach values $0.8 \%$ in the concrete core, i.e. in the confined concrete.

\subsection{Stiffness degradation}

The linear analysis theory is based on the constant stiffness of the structure, regardless of the degree of deformation of the structural elements. However, with the cracks appearance in the reinforced concrete elements and in the masonry infill, as well as, with the achievement of the yield strains in the reinforcement, the stiffness of the structure continuously degrades. The degree of degradation depends on the achieved deformation in the structural elements, which at global 
level are in function of the achieved lateral displacements. In Fig. 10 are presented the changes in the secant lateral stiffness, obtained as the ratio between the lateral force and the top displacements of the analysed frames. At low rise frames ( 2 and 3 storey), the initial lateral stiffness of the frames with open ground floor infilled with weak and strong infill is almost identical and is 2 to 3 times larger compared with the stiffness of the bare frames, but several times smaller than the rigidity of the frames with a continuous infill. With increasing the number of storeys, the differences in the lateral stiffness between the frames with the open first floor and the bare frames increases, unlike the differences in secant stiffness between the frames with open ground floor and continuous infill. The differences between the stiffness of the frames infilled with weak and strong infill are increased by increasing the number of storeys.

Fig. 11 shows the ratio between the secant and the initial lateral stiffness in function of the achieved lateral
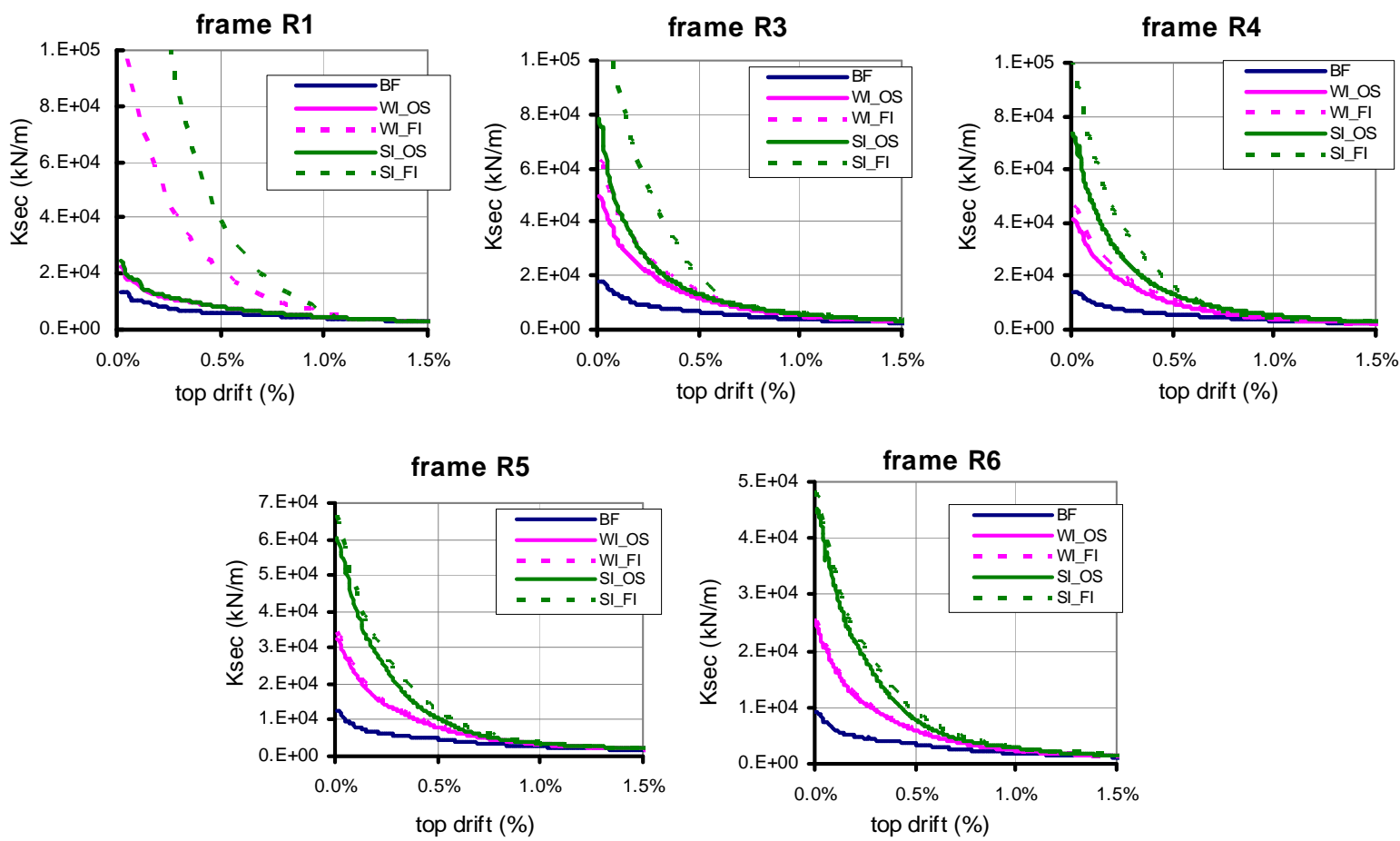

Fig. 10. Change on the secant stiffness of analysed frames
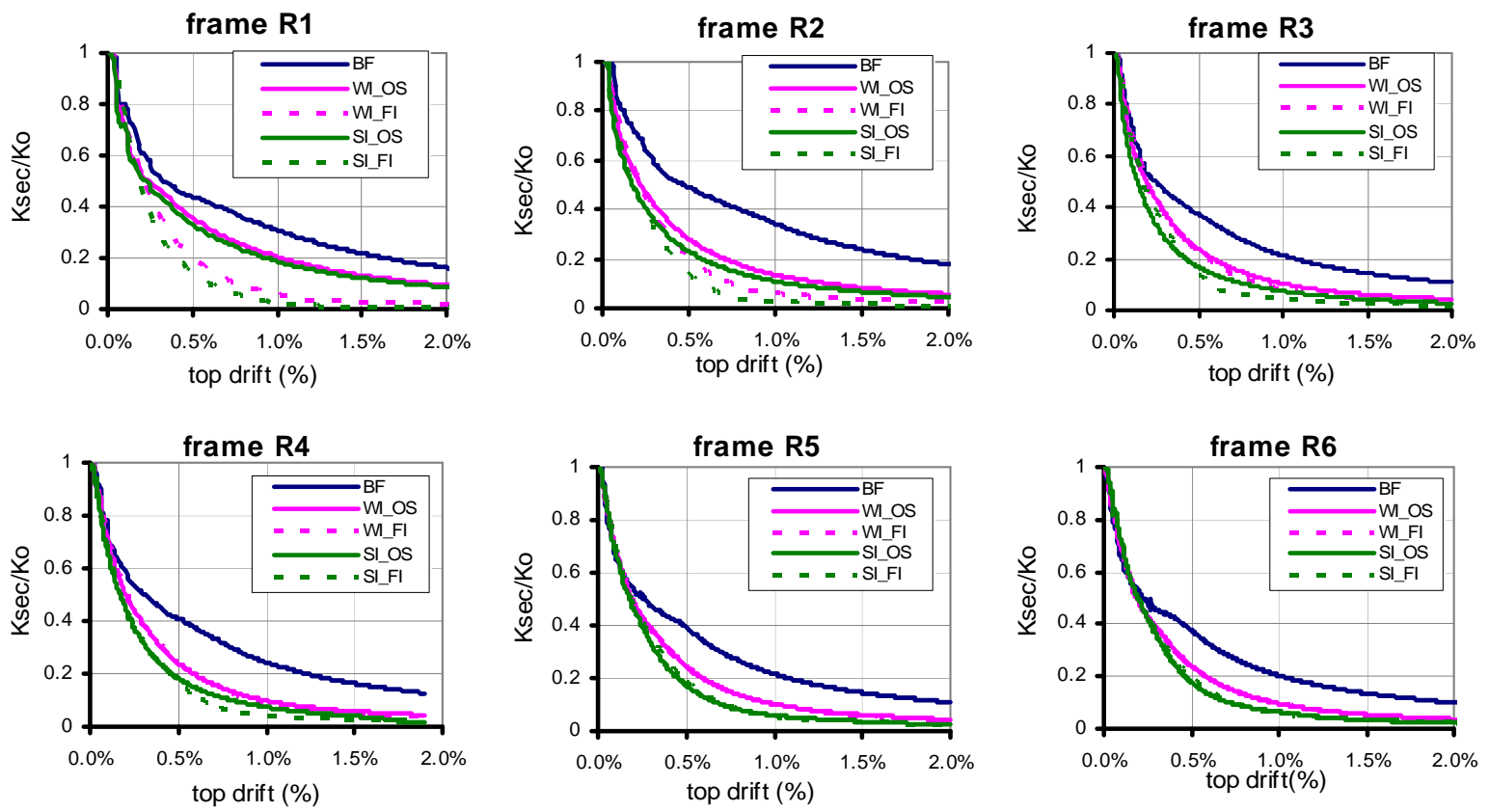

Fig. 11. Degree of stiffness degradation of analysed frames 
top drift. The degree of degradation of the lateral stiffness of the bare and infilled frames is almost identical with the top drift in range from $0.1 \%$ to $0.15 \%$, which is especially expressed at the higher frames. With the further increase of displacements, bare frames have a lower degree of degradation, compared with the infilled frames. The highest degree of degradation occurs in frames with a continuous infill over the entire height. Degree of degradation, almost does not depend on the number of storeys. At top drift equal to $0.5 \%$ of the total height, the secant stiffness, with respect to the initial ranges from $38 \%$ to $50 \%$ in the bare frames, is about $20 \%$ to $25 \%$ in the frames with an open ground floor and about $15 \%$ to $25 \%$ in frames with continuous infill.

At the moment of the appearance of the first plastic hinge, and due to the effects of cracks in reinforced concrete elements, the secant stiffness of the bare frames ranges from $42 \%$ to $47 \%$ in relation to the initial stiffness. These values are $3 \%$ to $8 \%$ lower than the recommendations for stiffness reduction according to Eurocode 8 (EN 1998-1:2004).

According to the obtained distribution of cracks through the structural elements, it can be noticed that the usual reduction of the stiffness is due to the appearance of cracks in the beam elements, in which the degree of cracks at the moment of first yield is significantly greater compared to the columns. This is especially expressed in the higher frames. The concept of equal reduction of stiffness in all elements is without greater impact on the global characteristics of the analysed structures, but it may have a significant impact on the redistribution of internal forces in structural elements with different degree of stiffness degradation.

\section{INCREMENTAL DYNAMIC ANALISIS}

An incremental dynamic analysis (IDA) is one kind of parametric nonlinear dynamic analysis that provides a continuous display, from elastic behaviour via yielding to the state of collapse, of the considered structures exposed to seismic action. The concept of incremental dynamic analysis was first proposed by Bertero [1], but a detailed description of the method and development of a methodology for its practical application was provided by Vamvatsikos and Cornell [30]. In this analysis structural model is exposed to one or more acceleration records, each of them scaled at multiple intensity levels. Incremental dynamic analysis is a pushover analysis pendant, with the difference that in the pushover analysis results are obtained with the incremental increase of static load, while in the incremental dynamic analysis with the increases of the intensity of the input ground motion. The results of the incremental dynamic analysis are presented in the so-called IDA curves, which give the connection between a certain intensity measure (IM) and the behaviour of the structure expressed through a certain measure of damage (DM). In order to carry out this analysis, it is necessary to define confidential data for the behaviour of structural materials and elements exposed to cyclic loading over the limit of elasticity, to select and to scale the acceleration ground motion and to define a stable algorithm for solving the system of differential equations of motion.

\subsection{Selection and scaling of earthquake ground motions}

In the probabilistic approach for the assessment of seismic performance, the analysis of the structural behaviour usually is performed for the multiple earthquake scenarios, while the evaluation of seismic performance is carried out by statistical processing of the obtained results. This approach allows determination of the probability of damage for a certain earthquake scenario and also allows identification of the ground motion records that have the greatest influence on the behaviour of a certain structure.

Each ground motion is characterized by a few engineering parameters, among which the parameters that characterize the amplitudes and the frequency content of the earthquake are the most important. In order to select records with defined frequency content from the existing database of earthquake ground motions, a methodology for the identification of dominant frequency domain in the acceleration spectrum was developed [29]. The developed methodology is based on the transformation of the acceleration spectrum into a modified cumulative spectral intensity diagram, which enables easy identification of the boundary periods of the dominant frequency range $\left(T_{1}\right.$ and $\left.T_{2}\right)$, the mean dominant period $\mathrm{T}_{\mathrm{m}}$, and the mean amplification of the acceleration spectrum. The defined procedure was applied to 910 registrations from the PEER NGA database [3], of which 21 registrations, divided into three groups of 7 records, Fig. 12, were selected and used for further analyses.
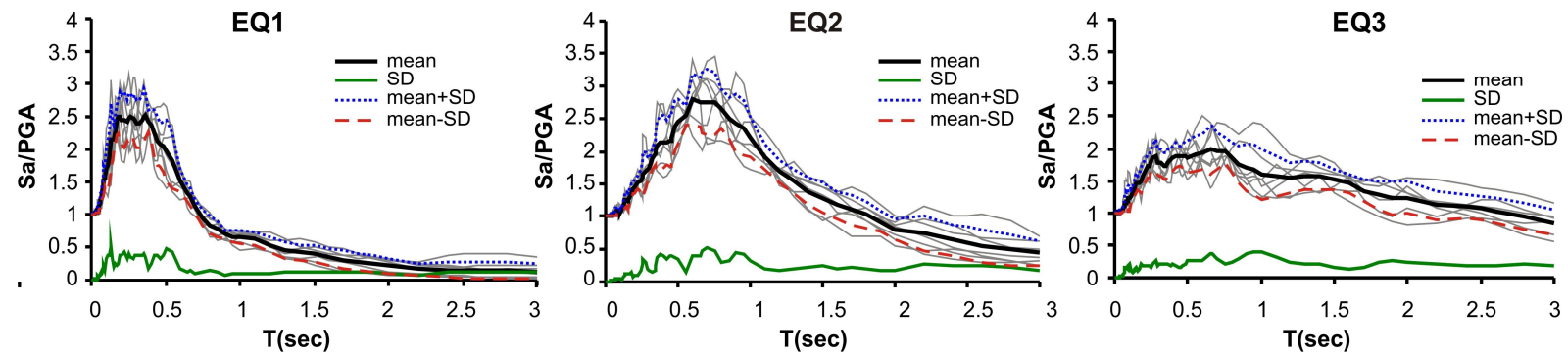

Fig. 12. Acceleration spectra of the selected records for analysis 
The first group of earthquakes (EQ1) contains registrations of earthquakes with a predominantly frequency range of low periods. The boundary values of the dominant frequency for this group of earthquakes is in the range from $\left(0.1 \mathrm{sec} .<\mathrm{T}_{1}<0.15 \mathrm{sec}\right.$.) to $\left(0.55 \mathrm{sec} .<\mathrm{T}_{2}\right.$ $<0.6 \mathrm{sec}$.). Thus, the width of the dominant frequency band, $\mathrm{B}_{\mathrm{T}}$, is confined within the limits $\left(0.4<\mathrm{B}_{\mathrm{T}}<0.5 \mathrm{sec}\right.$.), and the mean period $T_{m}$ is defined in boundaries from $0.325 \mathrm{sec}$ to $0.375 \mathrm{sec}$. This group of earthquakes should expose stiff structures to oscillate dominantly in the first mode, while more flexible structures to oscillate in higher mode shapes. The second group of earthquakes (EQ2) is defined by a predominantly frequency range of medium to high periods, $\left(0.24 \mathrm{sec} .<\mathrm{T}_{1}<0.35 \mathrm{sec}\right.$.) and $\left(1.1 \mathrm{sec} .<\mathrm{T}_{2}<1.5 \mathrm{sec}\right.$.). The width of the dominant frequency band in this group can range from 0.75 to 1.26 sec., while the median period can range from 0.725 to $0.91 \mathrm{sec}$. A third group of earthquakes (EQ3) is defined by the requirement that the width of the dominant frequency range is within 1.8 to $2.6 \mathrm{sec}$., without imposing limits on the boundary values for the periods of the dominant frequency range.

The procedure for records selection is carried out in two steps. In the first step, according to the defined limit values of the dominant frequency ranges that meet the set criteria, 45 records from group 1, 34 from group 2 and 55 from group 3 were selected. In the second step of selection, seven records with the smallest cumulative deviation were selected. The acceleration spectra of the selected records from each group, their mean spectrum, the standard deviation, and the mean spectrum \pm one standard deviation are presented at Fig. 12.

To meet the requirements of incremental dynamic analysis the selected records were scaled to ten different amplitudes, based on scaling of pick ground acceleration. The records from the first group of earthquakes were scaled for pick ground acceleration in the range from $0.1 \mathrm{~g}$ to $1.0 \mathrm{~g}$, while the records from the second and the third group of earthquakes for pick ground acceleration in the range from $0.05 \mathrm{~g}$ to $0.5 \mathrm{~g}$

\subsection{Analysis of the obtained results}

From the conducted nonlinear dynamical analyses, a large number of output data, which present the global response of the analysed structures, as well as a large number of results that show the structural response at the local level are obtained.
Maximum top displacements, expressed as a percentage of the total height of the analyed frames, are noted at lower frames. By the increasing of number of stories, the maximal top drifts are reduced, which is particularly pronounced for the case of earthquakes with a dominant frequency range of low periods. Bare frames (BF) have a larger top displacements compared with the infilled frames, which is more emphasized at lower levels of peak ground acceleration.

Infilled frames with strong infill (SI) reach smaller values of maximal top displacement compared to the frames with weak infill (WI), which is more significant for lower levels of peak ground acceleration and for higher frames. The frequency content of the ground acceleration records is the most influential factor on the degree of reached top drifts. The peak top displacement at the masonry infilled frames with an open first floor, calculated as the mean value from the results obtained for peak ground acceleration of $1 \mathrm{~g}$, for records characterized by a dominant frequency range of low periods, are within the range of $0.5 \%$ to $2 \%$ of the total height of the frames, Fig. 13. Similar values of the maximum top displacement, for the action of records with a predominantly frequency range of medium to high periods, as well as for registration with wide frequency content, are obtained for pick ground accelerations which are 3 to 4 times smaller compared to the records with dominant frequency range at low periods. Except to the influence on the level of maximum top displacement, masonry infill has a great influence on the distribution of displacements through the height, as well as on the distribution and amplitudes of the maximum inter-storey drifts.

At lower levels of peak ground acceleration, when the masonry infill is in the elastic domain of behaviour, it significantly stiffens the structure, and therefore reduces the maximum inter-story drifts. At higher levels of seismic action, i.e. when the degradation of the stiffness and strength of the infill occurs, the inter-storey drifts of the infilled frames increase significantly faster compared with the bare frames. Strong infill has a favourable effect on the degree of maximal inter-storey drifts to the certain level of peak ground acceleration. At higher level of PGA, the strongest infill leads to an undesirable failure mechanism, which increases the level of inter-story drifts. Relationship between maximum inter-storey drift and pick ground acceleration for analyzed frames exposed to second group of earthquakes is presented at Fig. 14.
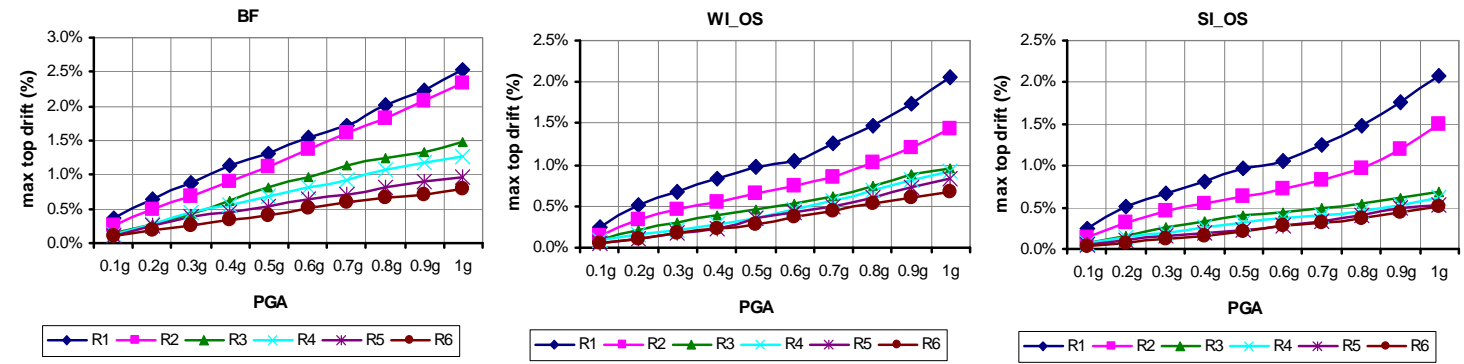

Fig. 13. Maximal top drift in function of pick ground acceleration for analysed frames exposed to first group of earthquakes 


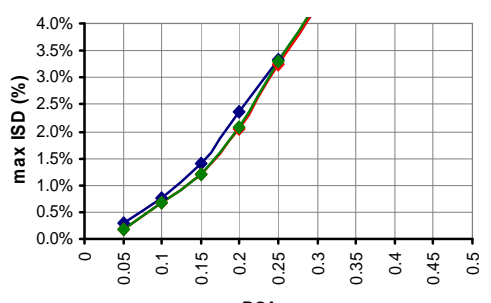

PGA
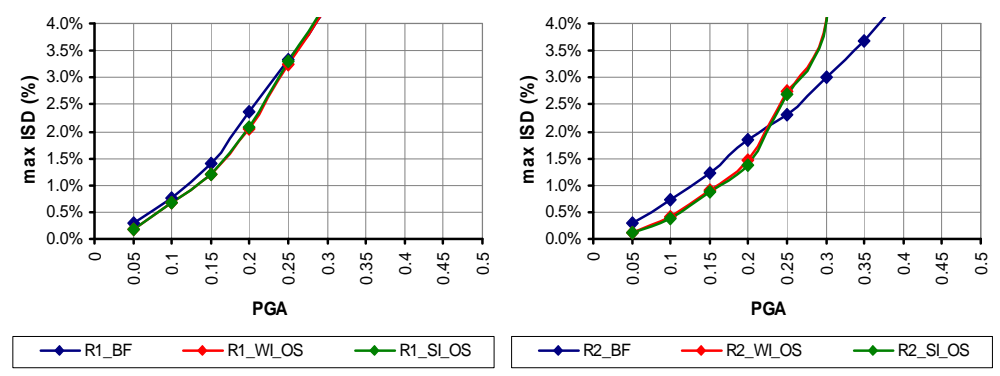

PGA

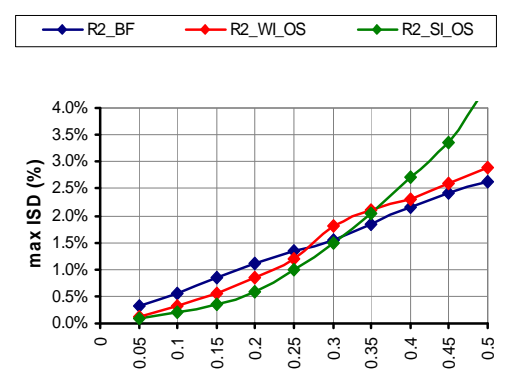

PGA

$\rightarrow$ R4_BF $\rightarrow$ R4_WI_OS $\rightarrow$ R4_SI_OS

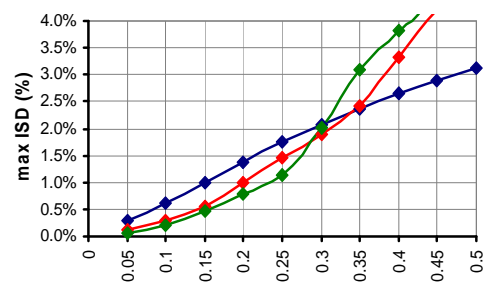

PGA
Fig. 14. Maximum inter-storey drift in function of pick ground acceleration for analysed frames exposed to the second group of earthquakes

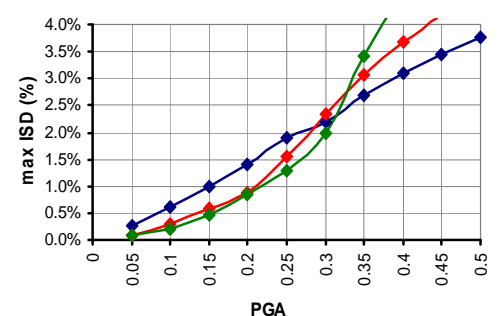

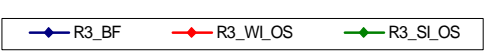

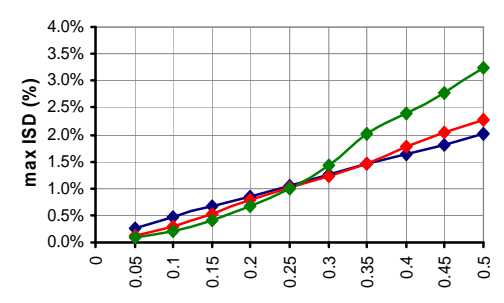

PGA

$\rightarrow$ R6_BF $\rightarrow$ R6_WI_OS $\rightarrow$ R3_SI_OS
Soft story mechanism of failure, expressed with the formation of plastic hinges at the ends of the columns on the first storey, where the infill is missing, is observed at the low frames with 2 and 3 storeys, regardless of the quality of the infill, as well as in the five storey frame with a strong infill, regardless of the characteristics of the ground motion, Fig. 15. At the higher frames, the failure mechanism is represented by the formation of plastic hinges in the beams and columns on the first few floors, Fig. 16.
Bare frame (BF)
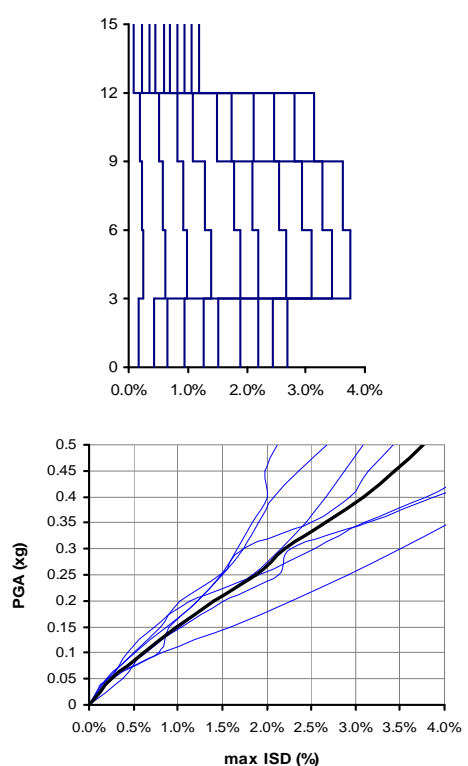

Fig. 15. Distribution of inter-storey drifts and IDA curves for five-storey frame R3 exposed to the second group

Fig. 15. Distribution of inter-storey drifts and IDA curves for five-storey frame R3 exposed to the second group
of earthquakes
Strong infill (SI)
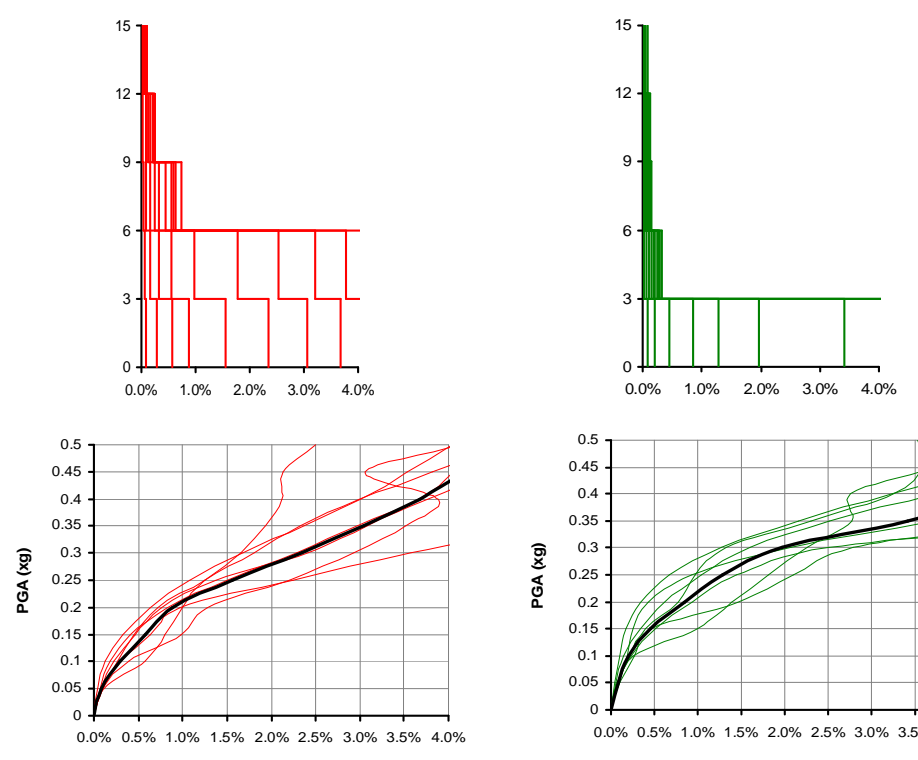

$\max$ ISD (\%)

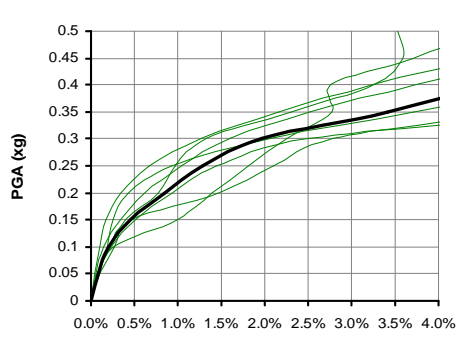

$\max$ ISD (\%) 

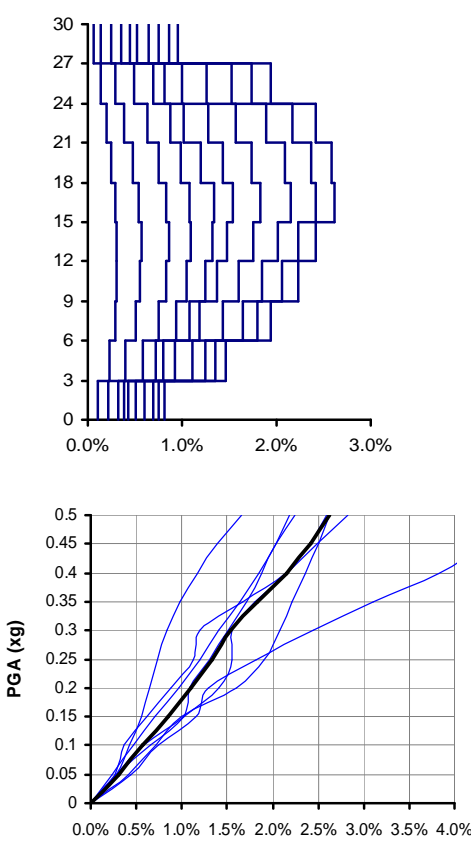

$\max$ ISD (\%)
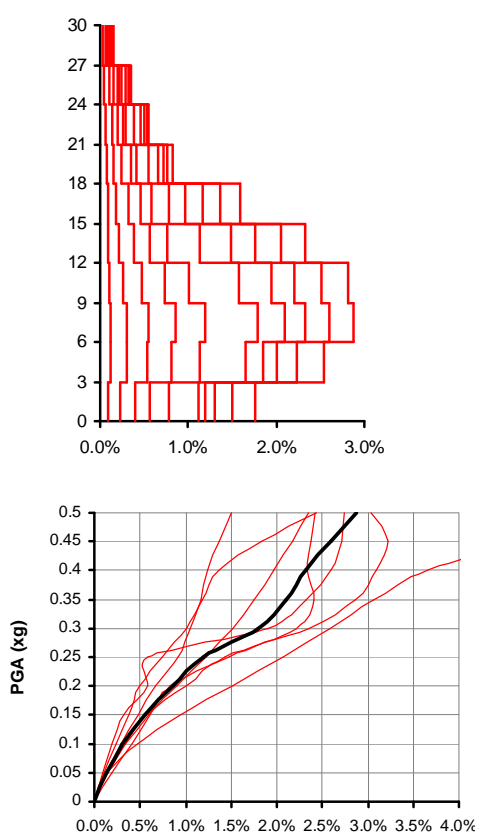

$\max$ ISD $(\%)$
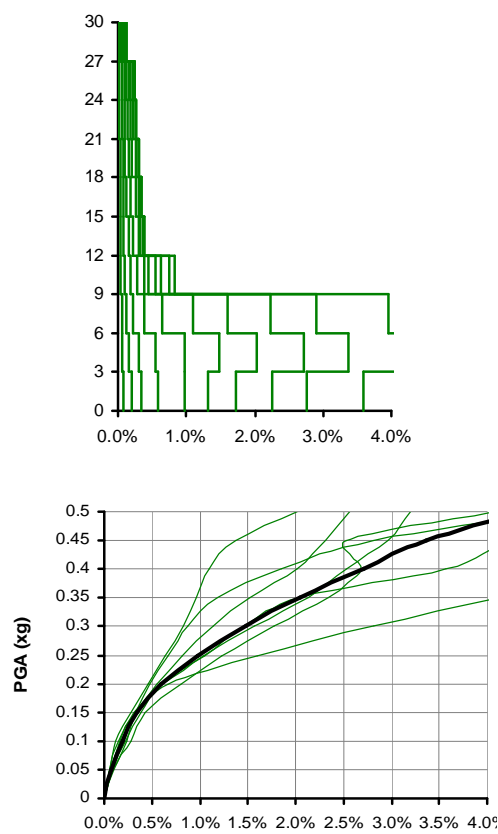

$\max I S D(\%)$

Fig. 16. Distribution of inter-storey drifts and IDA curves for ten storey frame $R 5$ exposed to second group of earthquakes

\subsection{Discrete levels of seismic performance}

The distribution of inter-storey drifts along the height is a direct indicator of the total damage degree that can occur within the frames for different earthquake scenarios. From the determined incremental curves, which present the relationship between the pick ground acceleration and maximum inter-story drifts, the discrete seismic performance levels can be determined.

Depending on the achieved strains in the infill, which are related with the inter-storey drifts, Table 2, four limit states of seismic performance are defined: operational $\left(\delta_{A}=0.12 \%\right)$, immediate occupancy $\left(\delta_{B}=0.45 \%\right)$, life safety $\left(\delta_{\mathrm{C}}=1.5 \%\right)$ and near collapse with maximum inter-story drift $\delta_{\mathrm{D}}=2.5 \%$. It should be noted that the same limit values of the inter-story drifts are used for all floors within the infilled frames, regardless of whether the extreme values appear at the level of the first open floor, or on any of the upper floors. In order to compare the results, the same limit values were used to define the limit states and for the bare frames.

For the action of the first group of earthquakes, the most vulnerable for all levels of seismic performance are low rise frames. The operational limit state for this group of earthquakes is achieved for peak ground acceleration in the range from $0.03 \mathrm{~g}$ for frame $\mathrm{R} 2$ to $0.16 \mathrm{~g}$ for frames $\mathrm{R} 5$ and $\mathrm{R} 6$ with weak infill or $0.2 \mathrm{~g}$ for frame R6 with strong infill. The immediate occupancy limit state in lower frames is achieved at PGA from $0.1 \mathrm{~g}$ to $0.12 \mathrm{~g}$, while in the higher frames, it increases to around $0.45 \mathrm{~g}$ for frames with weak infill or $0.57 \mathrm{~g}$ for frames with strong infill. The life safety limit state at lower frames is expected to be achieved for pick ground acceleration of about $0.4 \mathrm{~g}$, while in the higher frames this condition is not reached in the considered range of intensity. The near collapse limit state in frames with a strong infill is expected to be reached at peak ground acceleration in the range from $0.7 \mathrm{~g}$ for frames $\mathrm{R} 1$ and $\mathrm{R} 2$ to $1 \mathrm{~g}$ for frame R4. In the case of lower frames with weak infill this limit state is reached for $2 \%$ to $4 \%$ higher peak ground acceleration compared with the frames with strong infill, while in the higher frames the achievement of this limit state is not registered. The relationship between peak ground acceleration, number of storey and achieved limit states, for the first set of earthquakes is presented in Fig. 17.
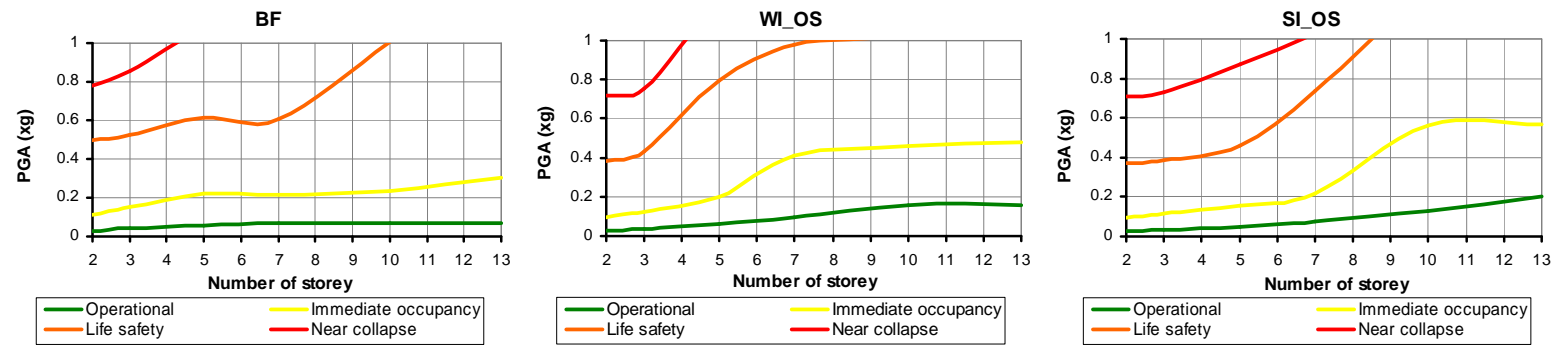

Fig. 17. Limit states of seismic performance for analysed frames exposed to first group of earthquakes 
The achievement of the defined limit states in the considered infilled frames, for the action of earthquakes from the second or third group, differs considerably compared to the first group, which is more significant at the higher limit states, Fig. 18 and Fig. 19. The operational limit state is achieved for the PGA from $0.05 \mathrm{~g}$ to $0.07 \mathrm{~g}$, for the action of the second group of records, up to a maximum value of $0.1 \mathrm{~g}$ for the frame $\mathrm{R} 5$ exposed to the third set of records. The state of immediate occupancy, for frames up to 5 storey exposed to the second group of earthquakes, is reached for PGA in the limits from $0.08 \mathrm{~g}$ to $0.15 \mathrm{~g}$, or from $0.1 \mathrm{~g}$ to $0.2 \mathrm{~g}$ for the action of earthquakes from the third group. At the higher frames with weak or strong infill, this condition is achieved at average PGA values from $0.13 \mathrm{~g}$ to $0.16 \mathrm{~g}$ for the second, or from $0.15 \mathrm{~g}$ to $0.2 \mathrm{~g}$ for the third set of records. The life safety limit state is achieved for peak ground acceleration from $0.17 \mathrm{~g}$ to $0.35 \mathrm{~g}$. Lower values of intensity usually are related to the lower frames, where the formation of the soft storey mechanisms at the level of the first storey occurs. Soon after the achievement of life safety limit state, the performance level of near collapse is reached. This limit state is reached for peak ground acceleration in range from $0.22 \mathrm{~g}$ to $0.42 \mathrm{~g}$, depending on the number of storeys and characteristics of the ground acceleration.

According to the achieved levels of seismic performance, it can be concluded that in order to provide the limit state of functionality, masonry infill, through the additionally added stiffness and strength, usually play a positive role, reducing the seismic demand. Due to the possibility of the appearance of a brittle failure in the infill, which can be reflected by the appearance of weak parts in the structure, it can be said that the masonry infilled frames are unreliable for providing higher limit states. In the lower frames with an open first floor, due to the presence of the infill on the upper floors, an undesirable soft storey mechanism usually occurs.

\section{COMPARISON OF RESULTS}

Nonlinear static and nonlinear dynamic analysis with a satisfactory degree of accuracy can predict the response of a structure when entering into a nonlinear region of behaviour, [8], [11], [12]. Due to take into account material nonlinearity both methods of analysis use similar material models. The same iterative methods are used to achieve the criteria of convergence and identification of the critical zones in the structure and prediction of the possible failure mechanism. Unlike nonlinear dynamic analysis that gives a direct relationship between the achieved nonlinear deformations and the level of seismic action, the nonlinear static analysis gives a continuous representation of the relationship between the total base shear and the top displacements, without providing discrete values of the reached displacement that will correspond to a certain level of seismic hazard. The relationship between the total base shear and the achieved displacement in the nonlinear static analysis depends on the distribution of lateral forces, while in the nonlinear dynamic analysis this relationship depends on the characteristics of the input ground motions, participation of mode shapes as well as the degree of equivalent viscous damping. An overview of the capabilities and general systematization of methods for seismic analysis of structures can be found in [4].

In order to perceive the possibility for prediction of a nonlinear dynamic response by application of a nonlinear static analysis, in the case of masonry infilled frames with open first floor, a direct comparison of the results obtained from these two analyses was made. The comparison of the results is based on two parameters that characterize the capacity curve obtained from the nonlinear static analysis, namely the top displacement and the total base shear. In nonlinear static analysis, for a known vector of distribution of lateral load, these parameters are uniquely defined, that
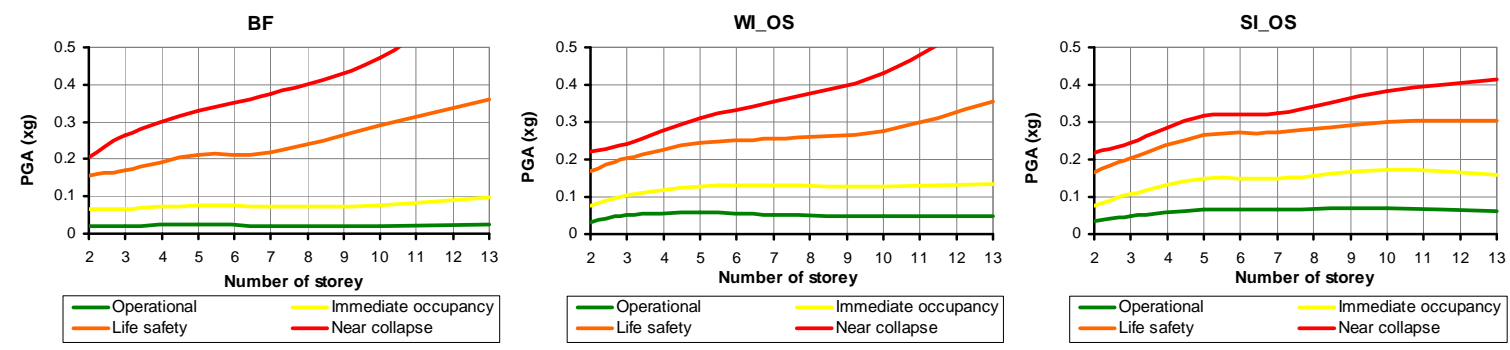

Fig. 18. Limit states of seismic performance for analysed frames exposed to second group of earthquakes
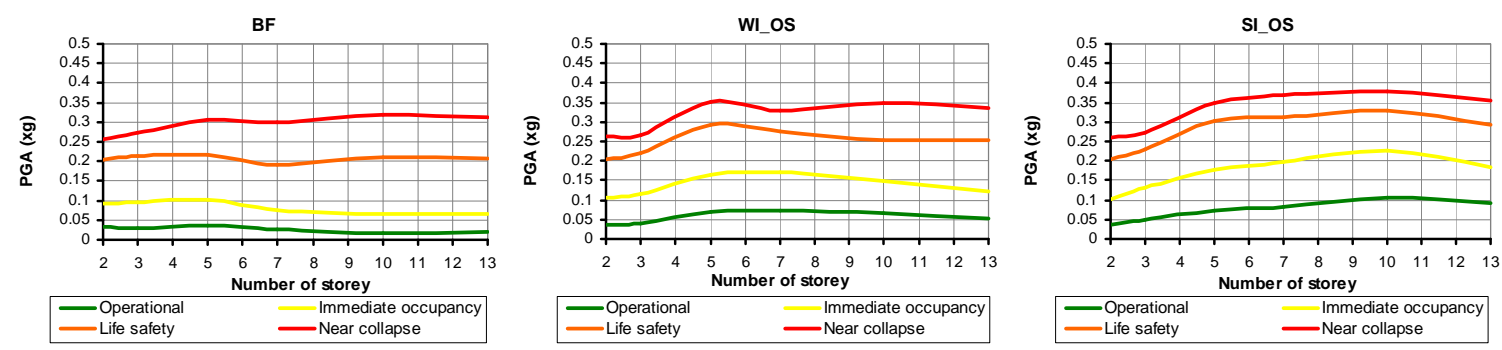

Fig. 19. Limit states of seismic performance for analysed frames exposed to third group of earthquakes 
is, each displacement corresponds to a defined level of the base shear. In nonlinear dynamic analysis, due to the degradation of the lateral stiffness and strength during the seismic action, several levels of total base shear can correspond to one level of displacement. Having in mind that nonlinear static analysis aims to present the envelope capacity of the structure, the selection of the results for comparison from the nonlinear dynamic analysis is reduced to the determination of the maximum values of the displacements and the total base shear. However, in that case, a three combinations of extreme values are possible:

- Maximum displacement - corresponding base shear,

- Maximum base shear - corresponding displacement,

- Maximum base shear - maximal displacement.

In the masonry infilled frames, due to the contribution of the infill on bearing capacity of the frame, the maximum base shear is reached at relatively small displacements, so the second and third variants of the combination of extreme values can lead to unrealistic comparison results. Namely, the second variant would limit the response to displacement when the maximum capacity is reached, while the third variant would give a combination of values even after achieving the displacement at maximum force, but would not be able to present the decreasing branch of the capacity curve which occurs after the achievement of the maximum strength and is the result of the degradation of the infill strength. In addition, attention should be paid to the direction of the lateral force and corresponding displacement. In certain cases, it is possible to compare the absolute maximums, not considering the direction, which can also lead to unrealistic results. To illustrate the differences that can arise from the combination of different extreme values, several comparisons have been made. In Fig. 20, part of the results obtained for the case of the frame R5 with strong infill exposed to the input ground motion from the third group of earthquakes are presented. The global hysteresis diagram (total base shear - peak displacement) for PGA equal to $0.45 \mathrm{~g}$, the capacity curve obtained from the nonlinear static analysis, for the distribution of the lateral force according to the first mode shape, and the three points corresponding to the three combinations of extreme values for the defined level of peak ground acceleration are presented in Fig. 20a. In addition to the capacity curve, through a series of points, the incremental relationship total base shear - top displacement for the three mentioned combinations of the extreme values obtained from the incremental dynamic analysis for the range of peak ground acceleration from $0.05 \mathrm{~g}$ to $0.5 \mathrm{~g}$ with step of $0.05 \mathrm{~g}$ are presented in Fig. 20b.

From the diagrams presented in Fig. 20 it can be noted that for small values of peak ground acceleration, the three combinations of extreme values give approximately the same results, which mainly overlap with the capacity curve obtained from nonlinear static analysis. The similar results of the three combinations are due to the fact that the maximum values of the displacement are attained at the same or close time moment with the moment when the maximum base shear occurs. This is especially expressed in lower frames where the first mode shape is dominant, so the increment of displacements corresponds to the increment of the total base shear. In higher frames, where higher mode shapes may have a significant impact in the distribution of lateral force by height, the total base shear may begin to decrease, and the top displacement continue to increase. For illustration, Fig. 21 presents one segment $(8.1$ to $8.42 \mathrm{sec})$ of the response histories
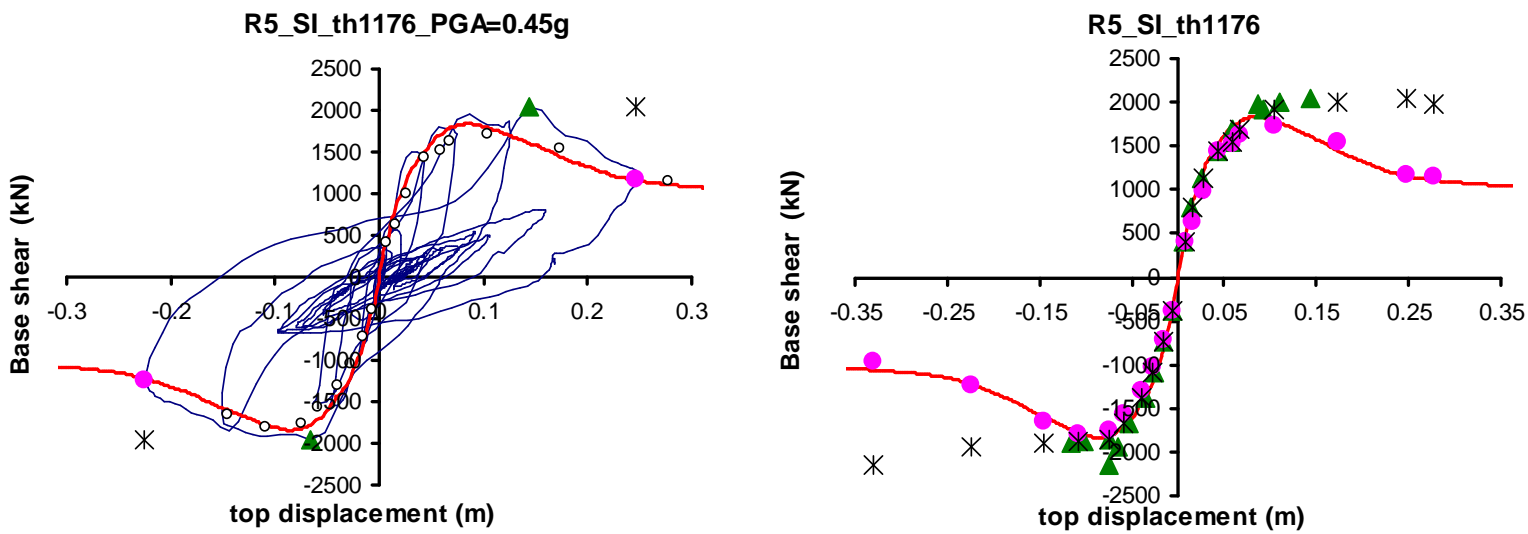

Fig. 20. Comparison of capacity curves obtained from nonlinear static and incremental dynamic analysis for different combinations of extreme values
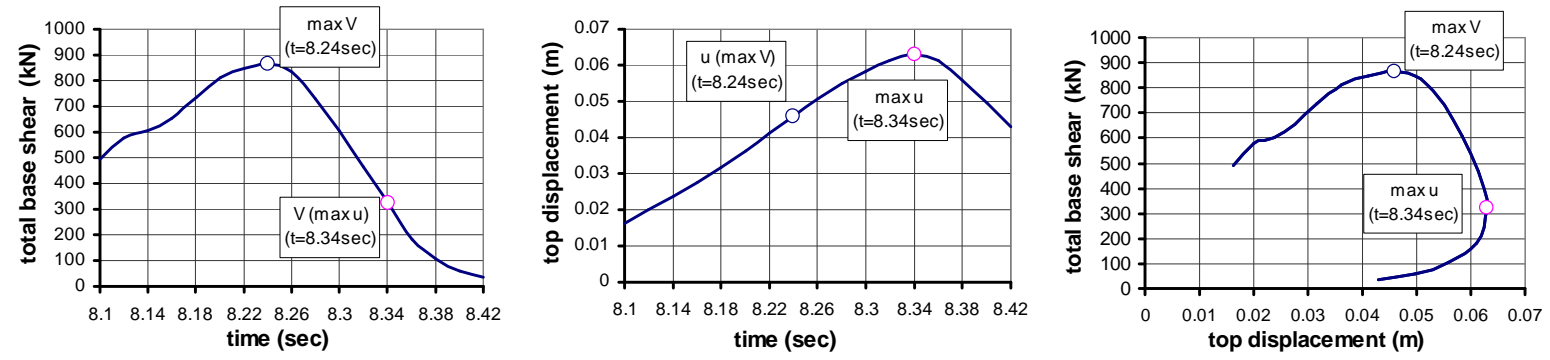

Fig. 21. Different time moments of reaching the extreme values of top displacement and lateral force due to the influence of higher mode shapes 

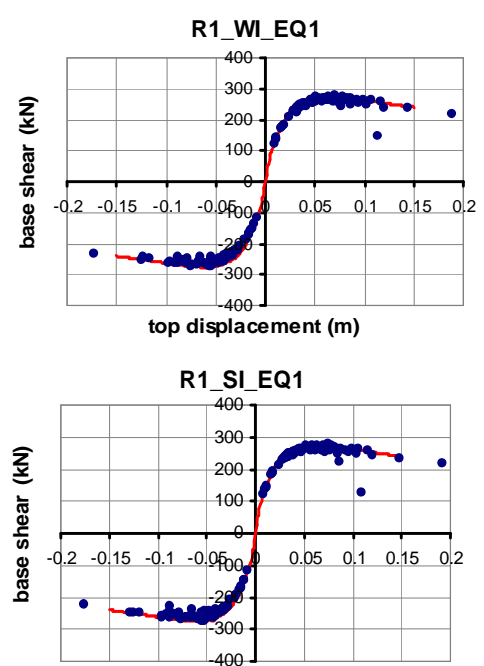

top displacement $(\mathrm{m})$

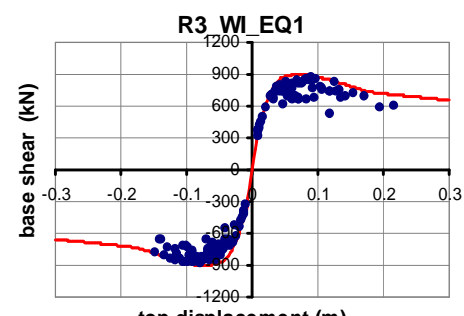

top displacement (m)

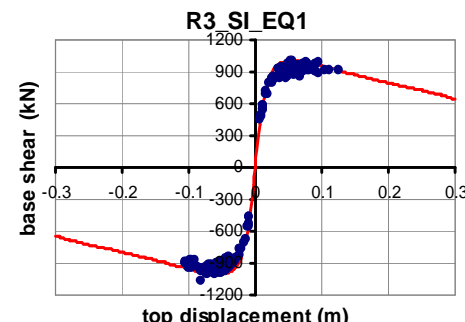

top displacement (m)

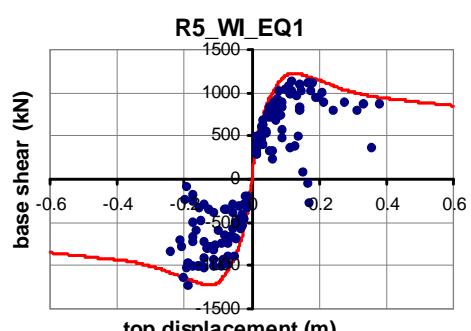

top displacement $(\mathrm{m})$

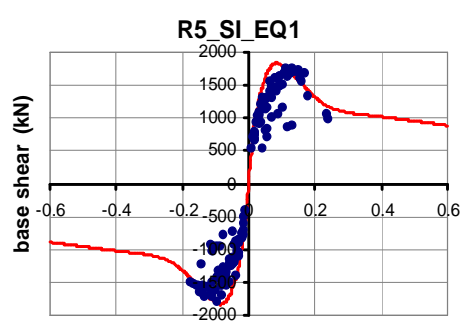

top displacement (m)

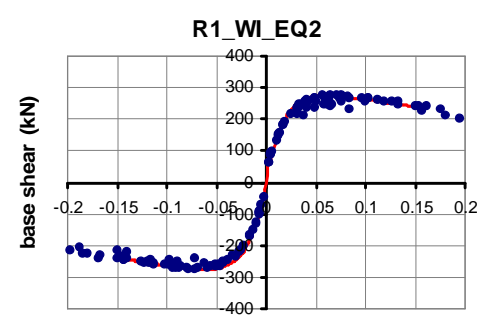

top displacement (m)

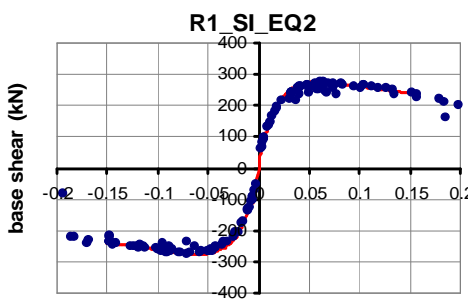

top displacement $(\mathrm{m})$

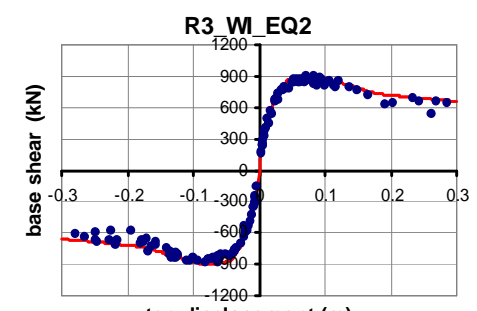

top displacement (m)

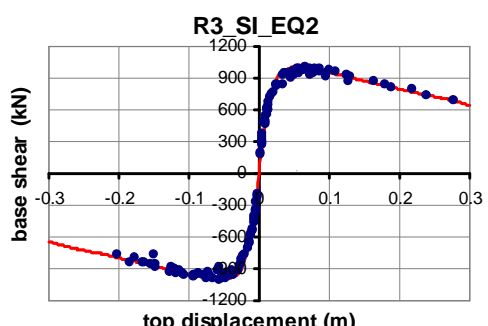

top displacement (m)

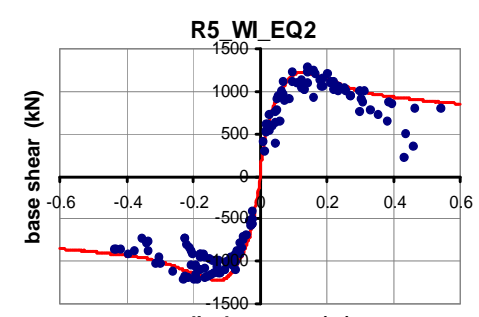

top displacement (m)

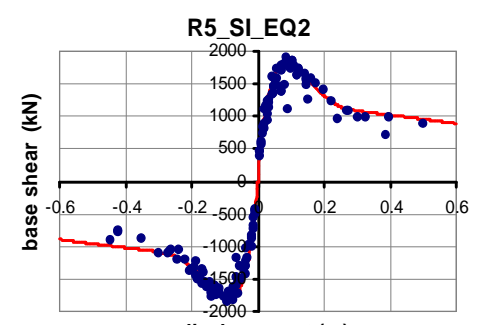

top displacement (m)

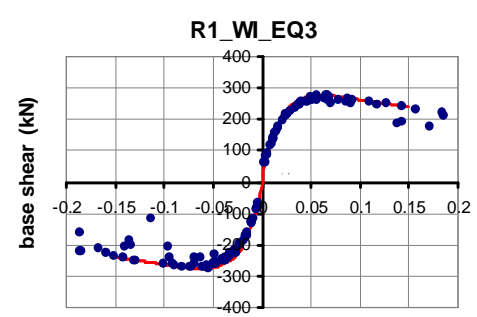

top displacement (m)

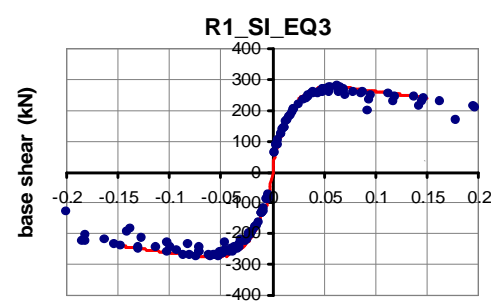

top displacement (m)

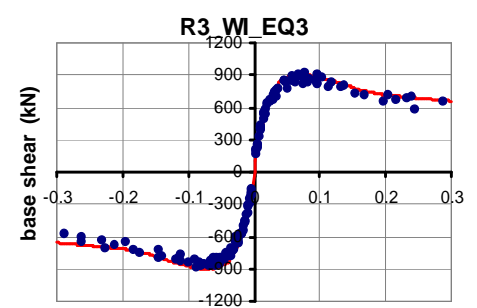

top displacement $(m)$

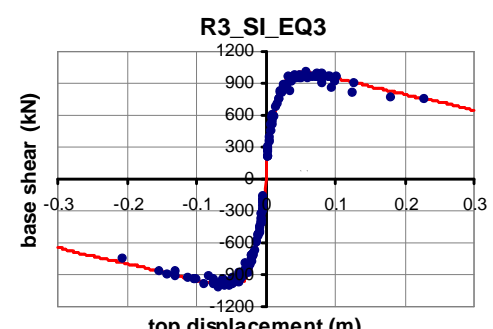

top displacement $(\mathrm{m})$

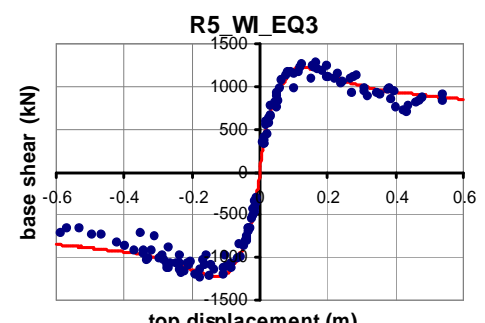

top displacement (m)

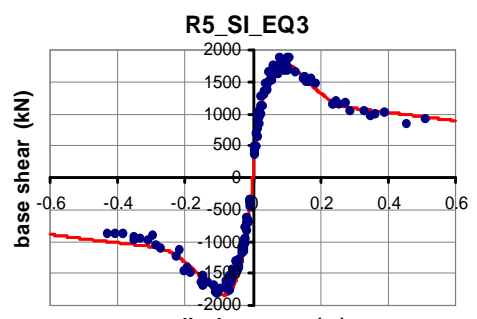

top displacement (m)

Fig. 22. Total base shear - top displacement relationship, obtained from nonlinear static and incremental dynamic analysis 
of the total base shear and the top displacement, as well as the hysteresis diagram total base shear - top

Fig. 22 presents maximum top displacement - appropriate base shear diagrams, for the analysed two (R1), five (R3) and ten (R5) story infilled frames, with the open first floor, obtained from the incremental dynamic analysis for the individual records from the selected three groups of earthquakes, as well as the corresponding capacity curves obtained from the nonlinear static analysis.

From the relationship maximum top displacement total base shear, obtained from the incremental dynamic analysis of the action of three groups of earthquakes for six analysed frames with a weak and strong infill, as well as from their comparison with the capacity curves obtained from the nonlinear static analysis, for the distribution of the lateral force according to the displacements in the first mode shape, the following observation can be noted:

- In lower frames R1, R2 and R3, there is almost an ideal overlap of the results obtained from the incremental dynamic and nonlinear static analysis, regardless of the quality of the infill and frequency contents or the intensity of the ground motions. Certain deviations can be noticed in the frames $R 1$ and $R 2$ exposed to the third group of earthquakes, as well as within the frames $R 2$ and $R 3$ exposed to the records from the first group of earthquakes. Deviations within the frames $R 1$ and $R 2$ are usually due to the achievement of large top displacements ranging from 1.5 to $2.5 \%$ of the total height of the frames at some previous time step, leading to significant degradation of the strength and stiffness. For illustration, Fig. 23 presents the hysteresis diagram total base shear - top displacement for the frame R1 with a weak infill obtained from the record of the third group of earthquakes with a peak ground acceleration equal to $0.5 \mathrm{~g}$. The maximum displacement in the negative direction for this record is $11.3 \mathrm{~cm}$ and is reached at time $\mathrm{t}=26.18 \mathrm{sec}$. once it was previously at the time moment $\mathrm{t}=22.6$ sec. a maximum displacement of $19.3 \mathrm{~cm}$ was

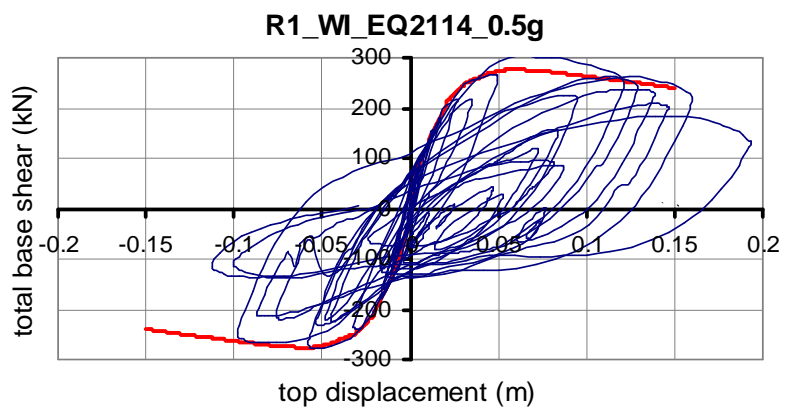

top displacement $(\mathrm{m})$ displacement, for the frame R5 with weak infill exposed to the ground motion from the first group of earthquakes. achieved in a positive direction. Significant degradation of the strength and stiffness has been caused due to the influence of the previous damage history in the opposite direction, so the system is no longer able to follow the envelope curve, i.e. to reach the lateral force at which the maximum displacement was achieved in some previous step.

- Deviations in results for the frame R3 with weak infill exposed to earthquake actions from the first group are due to the occurrence of significant damage in the infill on the upper floors and due to the impact of the higher mode shapes. Therefore, the maximum base shear that occur when the maximum displacements are reached is usually less than the base shear that correspond to the distribution of lateral force according to the first mode shape.

- In higher frames, R4 to R6, the greatest deviations occur in frames with weak infill exposed to the first group of earthquakes. For the action of this group of earthquakes deviations also occur in the frames $\mathrm{R} 5$ and R6 with a strong infill, but are smaller compared to the frames with weak infill.

- For the action of the second group of earthquakes, the greatest deviations occur in the frames R5 and R6 with weak infill. This is due to the fact that the period of dominant mode shape in these frames, and especially after the occurrence of damage, is shifted from the dominant frequency range of this group of earthquakes, while the period of the second mode shape enters in the area of maximum spectral amplifications.

- For the action of the third group of earthquakes, in a large number of cases there is a relatively good overlap of the results obtained from the incremental dynamic and nonlinear static analysis, which is mainly due to the frequency bandwidth of the records from this group of earthquakes. Exceptions to this are noted in the highest frame $\mathrm{R} 6$ with weak infill.

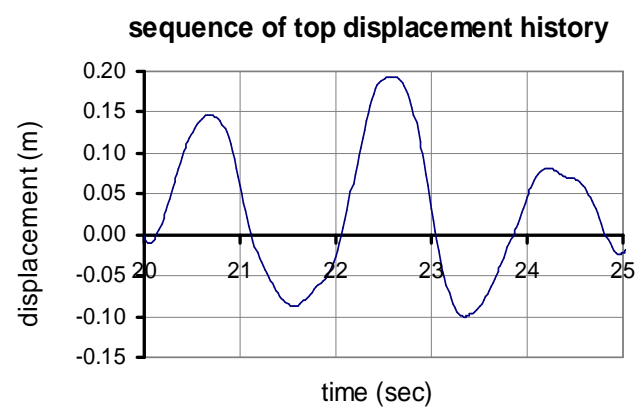

Fig. 23. Strength and stiffness degradation due to previous achieved large displacement in opposite direction

\section{CONCLUSIONS}

Presence of the masonry infill, its quality and irregular distribution in the height have a significant influence on the fundamental structural characteristics stiffness, strength and ductility. Masonry infill significantly affects the level of the lateral force that causes the appearance of the first plastic hinge, as well as the bearing capacity of the frames. The frames with a masonry infill and open first floor have greater bearing capacity compared to the bare frames due to the overstrength of the columns, as well as modification in the 
lateral loads bearing mechanism. With increasing the number of storeys, the ratio between the capacity of the bare frames and the infilled frames with open first floor increases. Unlike the increased capacity, the infilled frames show significantly smaller yield displacements and less ability to develop plastic deformations compared to the bare frames

There is a permanent degradation of the stiffness at the reinforced concrete frames with and without masonry infill with the development of cracks in the reinforced concrete elements and masonry infill, as well as appearance of yielding in the reinforced concrete elements. Degree of degradation in frames with and without infill is approximately equal until top displacement ranging from $0.1 \%$ to $0.15 \%$ of the total height. With increasing a displacement, the frames with the infill show faster degree of stiffness degradation compared to the bare frames. This tendency is more pronounced at frames with stronger infill compared to those with weaker infill. The number of storeys has insignificant effect on the

\section{REFERENCES}

[1] Bertero VV (1977). Strength and deformation capacities of buildings under extreme environments. Structural Engineering and Structural Mechanics. Pister, K.S. (ed.), Prentice Hall: Englewood Cliffs, NJ, pp. 211-215.

[2] Chandler AM, Lam NTK (2001). Performancebased design in earthquake engineering: A multidisciplinary review. Engineering Structures, 23: 1525-1543.

[3] Chiou B, Darragh R, Gregor N, Silva W (2008). NGA project strong-motion database. Earthquake Spectra, 24: 23-44.

[4] Ćosić M., Folić R, Brčić S (2017). An overview of modern seismic analyses with different ways of damping introduction. Building Materials and Structures, Vol. 60, No. 1, pp. 3-30, 2017.

[5] Crisafulli FG (1997). Seismic behaviour of reinforced concrete structures with masonry infills. Ph.D. Thesis. University of Canterbury, Christchurch, New Zealand.

[6] Decanini L, Mollaioli F, Mura A, Saragoni R (2004). Seismic performance of masonry infilled R/C frames. Proceedings of the 13th World Conference on Earthquake Engineering, Vancouver, B.C., Canada, August 1-6, Paper No. 165.

[7] Dolsek M, Fajfar P (2001). Soft storey effects in uniformly infilled reinforced concrete frames. Journal of Earthquake Engineering, 5(1): 1-12.

[8] Elnashai AS (2002). Do we really need inelastic dynamic analysis? Journal of Earthquake Engineering, 6(1): 123-130.

[9] Fardis MN, Negro P, Bousias SN, Colombo A (1999). Seismic design of open-storey infilled RC buildings. Journal of Earthquake Engineering, 3(2): 173-197.

[10] Fardis MN, Panagiotakos TB (1997). Seismic design and response of bare and masonry-infilled reinforced concrete buildings. Part II: infilled structures. Journal of Earthquake Engineering, 1(3): 475-503. degree of degradation of the stiffness of the analyzed frames.

The selection and characteristics of ground motion records are one of the most influential factors that directly affect the quality of the obtained results from nonlinear dynamic analysis. In the case of low rise buildings ( $n=2$ and 3 storeys), the quality of infill lack remarkable effect on the structural behaviour. Compared with the behaviour of bare frame, the presence of infill is usually unfavourable for all levels of PGA, leading to the formation of soft storey mechanism. In the case of 5 and 7 storey buildings, the presence of infill reduces the seismic demand up to the PGA of $0.3 \mathrm{~g}$. Usually, strong infill corresponds to small inter-storey drift demand, at low level of seismic hazard, compared with the weak infill. Soft storey mechanism has not been observed at high rise buildings. At this type of buildings distribution of damage depend on the mechanical characteristics of infill as well as the frequency content of input ground motion.

[11] Filippou FC, Ambrisi AD, Issa A (1992). Nonlinear static and dynamic analysis of reinforced concrete subassemblages. Report UCB/EERC-92/08, Earthquake Engineering Research Center, University of California, Berkeley.

[12] Fragiadakis M, Manolis P (2008). Modeling, analysis and reliability of seismically excited structures: Computational issues. International Journal of Computational Methods, 5(4): 483-511.

[13] Ghalehnovi M, Shahraki H (2008). Masonry infilling effect on seismic vulnerability and performance level of high ductility RC frames. AIP Conference Proceedings, 2008 Seismic Engineering Conference: Commemorating the 1908 Messina and Reggio Calabria Earthquake, Volume 1020, pp. 1727-1737.

[14] Ghobarah A (2001). Performance-based design in earthquake engineering: state of development, Engineering Structures 23, pp. 878-884.

[15] Kakaletsis DJ, Karayannis CG (2008). Influence of Masonry Strength and Openings on Infilled R/C Frames Under Cycling Loading, Journal of Earthquake Engineering, 12:197-221.

[16] Kappos AJ, Ellul F (2000). Seismic design and performance assessment of masonry infilled R/C frames, Proceedings of the 12th World Conference on Earthquake Engineering, 30 January-4 February, Auckland, New Zealand.

[17] Kappos AJ, Stylianidis KC, Michailidis CN (1998). Analytical models for brick masonry infilled $\mathrm{R} / \mathrm{C}$ frames under lateral loading. Journal of Earthquake Engineering, 2(1): 59-87.

[18] Kaushik HB, Rai DC, Jain SK (2006). Code approaches to seismic design of masonry-infilled reinforced concrete frames: A state-of-the-art review, Earthquake Spectra 22, 961-983.

[19] Korkmaz KA, Demir F, Sivri M (2007). Earthquake assessment of $\mathrm{R} / \mathrm{C}$ structures with masonry infill walls. International Journal of Science \& Technology, 2(2): 155-164. 
[20] Mander JB, Priestley MJN, Park R (1988). Theoretical stress - strain model for confined concrete. Journal of Structural Engineering, ASCE, 114 (8), $1804-1826$.

[21] Manfredi G, Ricci P, Verderame GM (2012). Influence of infill panels and their distribution on seismic behavior of existing reinforced concrete buildings. Open Constr. Build. Technol. J., 6: 236253.

[22] Moehle J, Deierlein GG (2004). A Framework Methodology for Performance-Based Earthquake Engineering, 13th World Conference on Earthquake Engineering, Vancouver, B.C., Canada, Paper No. 679.

[23] Monti G, Nuti C (1992). Nonlinear Cyclic Behavior of Reinforcing Bars Including Buckling. J. Struct. Eng., 118(12), 3268-3284.

[24] Murty CVR., and Jain SK (2000). Beneficial influence of masonry infill's on seismic performance of RC frame buildings, Proceedings of the 12th World Conference on Earthquake Engineering, New Zealand, Paper No. 1790.

[25] Porter KA (2003). An Overview of PEER's Performance-Based Earthquake Engineering Methodology, Ninth International Conference on Applications of Statistics and Probability in Civil

\section{SUMMARY}

\section{NONLINEAR STATIC VS. INCREMENTAL DYNAMIC ANALYSIS OF INFILLED FRAMES WITH OPEN FIRST FLOOR}

\section{Koce TODOROV \\ Ljupco LAZAROV}

Masonry infill, as a part of building structures, is characterised with significant in-plane strength and stiffness and it can greatly alter the response of structures exposed to seismic loads. Irregular distribution of infill in plane and along building height can lead to series of unfavourable effects (torsion effects, dangerous collapse mechanisms, soft or weak storey, variations in the vibration period, etc.).

In order to investigate the influence of irregular distribution of masonry infill to the seismic performance of code designed reinforced concrete frames, an extensive nonlinear static and dynamic analysis was performed. Six reinforced concrete frames with different number of storeys, designed as bare frames were analysed. In the phase of assessment, all structures were upgraded with the masonry infill panels in all storeys except the first one. Masonry infill was defined with two different strength and stiffness characteristics. The obtained results show significant influence of masonry infill on the main structural characteristics: strength, stiffness and ductility, as well as on the seismic performance of analysed frames.

Key words: nonlinear static, incremental dynamic; masonry infill; open ground floor
Engineering (ICASP9) July 6-9, 2003, San Francisco.

[26] Seismosoft (2013). SeismoStruct v6.0 - A computer program for static and dynamic nonlinear analysis of framed structures.

[27] Singh Y, Das D (2006). Effect of URM Infills on Seismic Performance of RC Frame Buildings, 4th International Conference on Earthquake Engineering, Taipei, Taiwan.

[28] Smyrou E, Blandon C, Antoniou S, Pinho R, Crisafulli $F$ (2011). Implementation and verification of a masonry panel model for nonlinear dynamic analysis of infilled RC frames. Bulletin of Earthquake Engineering, 9(5): 1519-1534.

[29] Todorov K (2014). Seismic performance of masonry infilled reinforced concrete frames with open first storey. PhD thesis, Faculty of Civil Engineering, University Ss. Cyril and Methodius, Skopje, R. Macedonia.

[30] Vamvatsikos D, Cornell CA (2002). Incremental dynamic analysis. Earthquake Engineering and Structural Dynamics, 31(3): 491-514.

[31] Code of Technical Regulations for the Design and Construction of Buildings in Seismic Regions, The Bureau for Standardization, Official Gazette of /former/ SFRY No. 31/81.

\section{REZIME}

\section{NELINEARNA STATIČKA NASUPROT INKREMENTALNE DINAMIČKE ANALIZE OKVIRA SA ISPUNOM SA OTVORENOM PRVOM ETAŽOM}

\section{Koce TODOROV \\ Ljupco LAZAROV}

Zidanu ispunu, kao deo građevinske konstrukcije, karakteriše značajna čvrstoća i krutost u ravni, i ona može da u velikoj meri izmeni odgovor konstrukcije izložene seizmičkom opterećenju. Nepravilna raspodela ispune u ravni i po visini građevine može da dovede do niza neželjenih efekata (efekat torzije, opasni mehanizmi Ioma, efekat "mekog sprata", varijacije perioda vibriranja, itd.).

Da bi se istražio uticaj nepravilne raspodele zidane ispune na seizmičke performanse projektovanih armirano-betonskih okvira prema odgovarajućim propisima, obavljene su obimne istraživanja koristeći nelinearnu statičku i dinamičku analizu. Analizirano je šest armiranobetonskih okvira različite spratnosti, projektovanih bez ispune. $U$ fazi procenjivanja, sve konstrukcije su nadograđene zidanom ispunom u svim spratovima osim prizemlja. Zidana ispuna je definisana pomoću dve različite čvrstoće i krutosti. Dobijeni rezultati pokazuju značajan uticaj zidane ispune na glavne konstruktivne karakteristike: čvrstoću, krutost i duktilnost, kao i na seizmičke performanse analiziranih okvira.

Ključne reči: nelinearna statička, inkrementalna dinamička; zidana ispuna, prizemlje bez ispune 